\title{
Biodegradable Alginate Films with ZnO Nanoparticles and Citronella Essential Oil-A Novel Antimicrobial Structure
}

\author{
Ludmila Motelica ${ }^{1, * \mathbb{D}}$, Denisa Ficai ${ }^{1}$, Ovidiu Oprea ${ }^{1, * \mathbb{D}}$, Anton Ficai ${ }^{1,2} \mathbb{D}$, Roxana-Doina Trusca ${ }^{1}$, \\ Ecaterina Andronescu 1,2 (D) and Alina Maria Holban 1,3 \\ 1 Faculty of Applied Chemistry and Materials Science, University Politehnica of Bucharest, \\ Spl. Independentei 313, 060042 Bucharest, Romania; motelica_ludmila@yahoo.com (L.M.); \\ denisa.ficai@upb.ro (D.F.); anton.ficai@upb.ro (A.F.); truscaroxana@yahoo.com (R.-D.T.); \\ ecaterina.andronescu@upb.ro (E.A.); alina.m.holban@bio.unibuc.ro (A.M.H.) \\ 2 Academy of Romanian Scientists, Ilfov st. 3, 050045 Bucharest, Romania \\ 3 Microbiology \& Immunology Department, Faculty of Biology, University of Bucharest, \\ 077206 Bucharest, Romania \\ * Correspondence: ovidiu.oprea@upb.ro or ovidiu73@yahoo.com; Tel.: +40-214023986
}

\section{check for} updates

Citation: Motelica, L.; Ficai, D.; Oprea, O.; Ficai, A.; Trusca, R.-D.; Andronescu, E.; Holban, A.M. Biodegradable Alginate Films with ZnO Nanoparticles and Citronella Essential Oil-A Novel Antimicrobial Structure. Pharmaceutics 2021, 13, 1020. https://doi.org/10.3390/ pharmaceutics 13071020

Academic Editors: Aurica P. Chiriac and Alina Gabriela Rusu

Received: 7 June 2021

Accepted: 30 June 2021

Published: 3 July 2021

Publisher's Note: MDPI stays neutral with regard to jurisdictional claims in published maps and institutional affiliations.

Copyright: (c) 2021 by the authors. Licensee MDPI, Basel, Switzerland. This article is an open access article distributed under the terms and conditions of the Creative Commons Attribution (CC BY) license (https:/ / creativecommons.org/licenses/by/ $4.0 /)$.

\begin{abstract}
The petroleum-based materials could be replaced, at least partially, by biodegradable packaging. Adding antimicrobial activity to the new packaging materials can also help improve the shelf life of food and diminish the spoilage. The objective of this research was to obtain a novel antibacterial packaging, based on alginate as biodegradable polymer. The antibacterial activity was induced to the alginate films by adding various amounts of $\mathrm{ZnO}$ nanoparticles loaded with citronella (lemongrass) essential oil (CEO). The obtained films were characterized, and antibacterial activity was tested against two Gram-negative (Escherichia coli and Salmonella Typhi) and two Gram-positive (Bacillus cereus and Staphylococcus aureus) bacterial strains. The results suggest the existence of synergy between antibacterial activities of $\mathrm{ZnO}$ and $\mathrm{CEO}$ against all tested bacterial strains. The obtained films have a good antibacterial coverage, being efficient against several pathogens, the best results being obtained against Bacillus cereus. In addition, the films presented better UV light barrier properties and lower water vapor permeability (WVP) when compared with a simple alginate film. The preliminary tests indicate that the alginate films with $\mathrm{ZnO}$ nanoparticles and $\mathrm{CEO}$ can be used to successfully preserve the cheese. Therefore, our research evidences the feasibility of using alginate/ZnO/CEO films as antibacterial packaging for cheese in order to extend its shelf life.
\end{abstract}

Keywords: biodegradable; alginate film; antibacterial packaging; citronella essential oil; zinc oxide nanoparticles; edible packaging; cheese

\section{Introduction}

Cheese, one of the most popular foods, is made of casein, fat and water, but unfortunately, when it is not salted, it has a limited shelf life. Extensive and uncontrolled microbial development on its surface is leading to the short shelf life of this kind of cheese. The need of bacterial cultures to produce the cheese varieties creates an infection hazard with cheese-borne species like Escherichia coli, Salmonella enterica or Staphylococcus aureus [1]. At present, the majority of food packaging used in industry is based on petrochemical polymers or cellulose due to low-cost and good mechanical and barrier performances [2]. Environmental concerns are building up pressure in favor of biodegradable packaging, from renewable sources like cellulose-based materials [3]. The majority of plastics used as packaging are not biodegradable and represent an environmental hazard worldwide increasing short- and long-term pollution [4]. Nevertheless, neither cellulose nor plastic packaging materials present antimicrobial activity. The environmental factors and the need to decrease food losses are constantly pressuring the food packaging industry to develop new types of antimicrobial and biodegradable materials. Such innovative materials can 
actively control the microorganisms' proliferation, reducing the food loss by spoilage, prolonging the shelf life and in the end ensuring a better food quality and safety [5-8].

Sodium alginate (A) is the salt of alginic acid, which belongs to polysaccharides and as such is a biocompatible and biodegradable polymer. Most often, the alginate is obtained from marine algae. The polymeric structure is composed from $\alpha$-l-guluronate $(\mathrm{G})$ and $\beta$-dmannuronate (M) units linked by $\beta-1-4$ glycosidic bond, which can form MM, GG or MG blocks [9]. Alginate is water-soluble, can be easily handled and functionalized [10], and is a natural choice for active packaging due to its lack of toxicity [11,12], US-FDA considering it as GRAS (Generally Recognized As Safe) [13]. Plasticizers are usually added to improve some of the mechanical properties of alginate films, glycerol being most often used due to its good compatibility [14]. Mechanical properties can be enhanced furthermore by reinforcing the biopolymer with nanoparticles (NPs), their inclusion improving also the barrier properties. Some nanoparticles, e.g., $\mathrm{ZnO}$, will act like crosslinking agents when they are embedded into the alginate matrix $[15,16]$.

Some of the properties of $\mathrm{ZnO}$ lead to applications that make it one of the most studied nanomaterials. $\mathrm{ZnO}$ has a high absorbance under $380 \mathrm{~nm}$ and therefore is often used as sunscreen, and it is used as a biocide in the medicine or food industry due to its potent antimicrobial activity [17-21]. Like many other nanoscale materials, $\mathrm{ZnO}$ nanoparticles present a large surface area, good loading capacity and potent antimicrobial activity [5]. While many papers explored the antibacterial activity of $\mathrm{ZnO}$, the antimycotic activity is seldom investigated [22-26]. The antimicrobial mechanism supposedly involves two separate pathways, in the presence of light and in the dark. The strong antimicrobial activity exhibited in the presence of light is due to reactive oxygen species (ROS) production, $\mathrm{ZnO}$ presenting a good photocatalytic activity. The ROS are responsible for the antibacterial activity, as they will damage the bacterial membrane by oxidative stress. In the absence of light the antibacterial activity is smaller, but still noticeable, the most probable mechanisms involving nanoparticle internalization and some mechanical damage, like puncture or rupture of the bacterial cellular wall [27-30]. Very important, US-FDA consider ZnO as GRAS and acceptable as an active component in food packaging due to its good antimicrobial properties [31-33].

Essential oils and other plant extracts present a huge potential as antibacterial and antioxidant agents and therefore are the subject of many research studies [34-37]. The major constituents of citronella essential oil (CEO), among other substances, are citral, citronellal and citronellol [38,39]. CEO is considered a non-toxic biopesticide in the US [40] which also has a very strong antifungal and antibacterial activity [41-43]. The bare alginate films exhibit a poor performance regarding water vapor permeability (WVP). In order to decrease the hydrophilicity of the alginate films, hydrophobic plant extracts or essential oils can be added into the composition [44-46].

The introduction of $\mathrm{ZnO}$ nanoparticles into the food packaging will enhance the antibacterial activity [14] and will improve the UV-barrier of the polymeric film. Both qualities will extend the shelf life of the packed food [47], but there is an associated concern about the risks posed by the potential migration of NPs into the food, and further into the human body. The antibacterial activity of the NPs comes from the interaction with microbial cells, but at the same time the ZnO NPs can interact with human cells. In order to enhance the antibacterial activity of the packaging films, the $\mathrm{ZnO}$ can be loaded with other potent agents [48-50]. The use of a natural antimicrobial agent, like an essential oil, along with $\mathrm{ZnO}$ permits the use of low concentration for nanoparticles due to the synergic action. When $\mathrm{ZnO}$ nanoparticles are used as antibacterial agent the concentration is small enough to be considered harmless, but safety issues are increased if $\mathrm{ZnO}$ is used for a long time, due to accumulation and higher concentrations being obtained [51]. Special concerns are related to the nano form when ingested [52]. Studies presenting $\mathrm{ZnO}$ nanoparticles cytotoxicity if ingested or applied onto human skin are reported [53-55] as a consequence of their widespread uses. While the information obtained on human exposure in realistic uses remains scarce [56], the results reported for the cytotoxicity of ZnO NPs at concentrations 
that are much higher than would be expected for normal exposure (topical, ingestion or inhalation) [57] remain controversial. Furthermore, negative results were obtained for all in vivo and the majority of in vitro genotoxicity tests for ZnO NPs [58-60]. While small $\mathrm{ZnO}$ quantities upon ingestion can be assimilated as a beneficial $\mathrm{Zn}^{2+}$ source, more studies are needed in order to assess its safety for long-term exposure [61]. At the used CEO concentrations the studies report no toxicity, but some concerns exist about the possible impact on beneficial gut bacteria [62,63].

Our objective in this research was to obtain an antibacterial, biodegradable packaging material, capable of extending food shelf life. As a model, we chose a traditional sort of cheese that usually can be kept only for 4 days in the fridge $\left(4-8{ }^{\circ} \mathrm{C}\right)$ after packaging is opened. The literature presents many reports of alginate packaging for various cheese assortments, especially in recent years [13,64-67]. Some contain essential oils or other plant extracts as antimicrobial agents $[68,69]$. While there are reports for chitosan or cellulosic edible films with $\mathrm{ZnO}$ nanoparticles for cheese packaging [70,71], in the alginate case none of them contain $\mathrm{ZnO}$. There are few reports of alginate- $\mathrm{ZnO}$ packaging films for fruits $[14,72]$. Therefore, alginate was chosen as the film forming biopolymer, in which $\mathrm{ZnO}$ nanoparticles were added as filler and antibacterial agent. In order to enhance the antibacterial activity of the nanocomposite films, the $\mathrm{ZnO}$ nanoparticles were loaded with citronella essential oil (CEO). To the best of our knowledge, this is the first time when an alginate-based packaging with ZnO NPs loaded with citronella essential oil is obtained. The biological tests against two Gram-positive and two Gram-negative bacterial strains indicate that a synergic effect was obtained between $\mathrm{ZnO}$ and $\mathrm{CEO}$, the nanocomposite films presenting a good antibacterial activity against all four strains.

\section{Materials and Methods}

\subsection{Materials}

Zinc acetate dihydrate with $99.9 \%$ purity and absolute ethanol were obtained from Merck. Sodium alginate (CAS 9005-38-3) was purchased from Fisher Scientific U.K. Ltd. (Redox Lab Supplies, Bucharest, Romania). Phosphate-buffered saline (PBS), Glycerol, Nutrient Broth, and agar were obtained from Sigma Aldrich (Redox Lab Supplies, Bucharest, Romania). Citronella essential oil (CEO) was purchased from Carl Roth (Amex-Lab, Bucharest, Romania). All the chemicals were used without any further purification.

The soft telemea cheese (S.C. Fabrica de lapte Brasov S.A., Halchiu, BV, Romania) was obtained from a local supermarket in Bucharest, Romania.

\subsection{Synthesis of $\mathrm{ZnO}$ Nanoparticles}

$\mathrm{ZnO}$ synthesis was performed as described previously in [73]. Briefly, $2.1950 \mathrm{~g}$ $\mathrm{Zn}\left(\mathrm{CH}_{3} \mathrm{COO}\right)_{2} \cdot 2 \mathrm{H}_{2} \mathrm{O}$ was dissolved in $50 \mathrm{~mL}$ absolute ethanol and heated at boiling point under magnetic stirring for $10 \mathrm{~h}$. The obtained precipitate was washed twice with water and finally with ethanol. The separation was done by centrifugation and the resulting powder was dried at $105^{\circ} \mathrm{C}$.

\subsection{Synthesis of Alginate/ZnO/CEO Films}

A certain amount of $\mathrm{ZnO} N$ Ps were suspended in $10 \mathrm{~mL}$ water and mixed with $1 \mathrm{~mL}$ CEO. The obtained suspension was sonicated for $30 \mathrm{~min}$ before being used to prepare AZ1-AZ4 films (Table 1).

Alginate films were obtained by solvent casting method. In total, $3 \mathrm{~g}$ alginate was added in $100 \mathrm{~mL}$ water and left to dissolve under stirring for $24 \mathrm{~h}$. Then, $2 \mathrm{~mL}$ of glycerol was added to the obtained alginate solution. The previously prepared $\mathrm{ZnO \& CEO}$ suspension was added to the alginate solution, under vigorous stirring.

Each solution was put in a Petri dish and was left to dry in an oven for $24 \mathrm{~h}$ at $40{ }^{\circ} \mathrm{C}$. A control film without ZnO NPs and CEO was prepared in the same way. After film drying, $200 \mathrm{~mL} \mathrm{CaCl}_{2}$ solution $(0.2 \mathrm{M})$ was added to each Petri-dish and the films were left 
submerged for $5 \mathrm{~min}$. The films were removed from the Petri-dish and were stored in zip lock plastic bags at $20^{\circ} \mathrm{C}$ and $60 \%$ relative humidity (RH).

Table 1. The alginate-ZnO NPs-citronella essential oil (CEO) films composition.

\begin{tabular}{ccccc}
\hline Sample Code & $\begin{array}{c}\text { Alginate (g in } \\
\mathbf{1 0 0} \text { mL Water) }\end{array}$ & $\begin{array}{c}\text { ZnO NPs (g in } \\
\mathbf{1 5} \text { } L \text { Water) }\end{array}$ & $\begin{array}{c}\text { Glycerol } \\
\text { (mL Solution) }\end{array}$ & CEO (mL) \\
\hline A & 3.00 & 0.00 & 2 & 0 \\
AZ1 & 3.00 & 0.05 & 2 & 1 \\
AZ2 & 3.00 & 0.10 & 2 & 1 \\
AZ3 & 3.00 & 0.25 & 2 & 1 \\
AZ4 & 3.00 & 0.50 & 2 & 1 \\
\hline
\end{tabular}

\subsection{Characterization of Alginate Composite Films}

\subsubsection{Microstructural Analysis}

In order to investigate the films surface morphology and microstructure scanning electron micrographs were obtained using a QUANTA INSPECT F50 scanning electron microscope (FEI Company, Eindhoven, The Netherlands) equipped with field emission gun-FEG with $1.2 \mathrm{~nm}$ resolution and an energy dispersive X-ray spectrometer (EDS) with an $\mathrm{MnK}$ resolution of $133 \mathrm{eV}$. K $\alpha$ lines, specific to each element, were used to map the distribution of $\mathrm{C}, \mathrm{O}$ and $\mathrm{Zn}$ across the sample's surface.

\subsubsection{Fourier Transform Infrared Spectroscopy}

By using Fourier transform infrared spectroscopy (FTIR) in the wavenumber range $4000-400 \mathrm{~cm}^{-1}$ we investigated the presence of certain functional groups and the interactions between some components of the nanocomposite films. A Nicolet iS50 FTIR spectrometer (Thermo Fisher Scientific Inc., Waltham, MA, USA), equipped with a DTGS detector, was used to record the spectra. We used a resolution of $4 \mathrm{~cm}^{-1}$, and each spectra was obtained by averaging 32 scans.

FTIR 2D maps were recorded with a Nicolet iS50R FTIR microscope (Thermo Fisher Scientific Inc., Waltham, MA, USA), with DTGS detector, in the wavenumber range $4000-600 \mathrm{~cm}^{-1}$. The 2D FTIR maps were used to obtain information about the spatial distribution of the components

\subsubsection{Photoluminescence Spectroscopy}

A Perkin Elmer (Waltham, MA, USA) LS55 spectrometer was used to measure the photoluminescence spectrum (PL). The configuration is using a Xe lamp as a UV light source at ambient temperature, the fluorescence being measured in the range $350-800 \mathrm{~nm}$. The spectra were recorded with a scan speed of $200 \mathrm{~nm} \mathrm{~min}^{-1}$, excitation and emission slits of $10 \mathrm{~nm}$, and a $1 \%$ attenuator (only $1 \%$ of the actual fluorescence is recorded, as the full emission is exceeding the spectrometer scale). An excitation wavelength of $320 \mathrm{~nm}$ was used.

\subsubsection{UV-Vis Spectroscopy}

A JASCO V560 spectrophotometer (JASCO Inc., Easton, PA, USA) was used to measure the UV-Vis spectra. The device was equipped with a $60 \mathrm{~mm}$ integrating sphere (ISV-469) and a film holder for the samples. The spectra were recorded with a speed of $200 \mathrm{~nm} \mathrm{~min}{ }^{-1}$, in the domain 200-900 $\mathrm{nm}$.

The opacity values were calculated as $\mathrm{A}_{600} / x=-\log \mathrm{T}_{600} / x$, where $\mathrm{A}_{600}$ is the absorbance at $600 \mathrm{~nm}, \mathrm{~T}_{600}$ is the fractional transmittance at $600 \mathrm{~nm}$ and $x$ is the film thickness in $\mathrm{mm}$. A higher opacity value indicates that the film is less transparent [74].

\subsubsection{Thermal Analysis}

Thermal analysis, TG-DSC, was performed with a STA 449C Jupiter apparatus, from Netzsch (Selb, Germany). Each sample weighed approximatively $10 \mathrm{mg}$. The samples were 
placed in an open alumina crucible and heated up to $900{ }^{\circ} \mathrm{C}$ with $10 \mathrm{~K} \cdot \mathrm{min}^{-1}$ rate, under flow of $50 \mathrm{~mL} \cdot \mathrm{min}^{-1}$ dried air. As reference, we used an empty alumina crucible. The evolved gases were analyzed with a FTIR Tensor 27 from Bruker (Bruker Co., Ettlingen, Germany), equipped with a thermostated gas cell.

\subsubsection{Water Vapor Permeability (WVP)}

For the determination of water vapor permeability (WVP) we used permeation cups with a diameter of $30 \mathrm{~mm}$, sealed with a sample film, as described in [75]. In each cup we placed $1 \mathrm{~g}$ of dried $\mathrm{CaCl}_{2}$. The permeation cups were placed in a container at a temperature of $25^{\circ} \mathrm{C}$ and $100 \%$ relative humidity. Their weight was measured at fix intervals $(8 \mathrm{~h})$ for four days.

\subsubsection{Swelling Capacity}

The swelling capacity was determined as described in [76]. Shortly, square samples of $\sim 3 \times 3 \mathrm{~cm}$ were cut from the fresh films and were dried in a desiccator for $48 \mathrm{~h}$. Once dried, the samples were weighed $( \pm 0.2 \mathrm{mg})\left(\mathrm{W}_{0}\right)$, then placed in $200 \mathrm{~mL}$ water or phosphate buffer saline (PBS) to allow swelling. The samples were weighted at each $30 \mathrm{~min}$ for three hours, and at $24 \mathrm{~h}$ intervals for next two days as the maximum swelling capacities were attained. The Equation (1) formula for degree of swelling (D) was used to calculate the swelling ratio:

$$
\mathrm{D}=\left(\mathrm{W}_{\mathrm{t}}-\mathrm{W}_{0}\right) / \mathrm{W}_{0}
$$

\subsection{Antibacterial Assay}

The antibacterial activity was evaluated against model Gram-positive (Bacillus cereus ATCC 13,061 and Staphylococcus aureus ATCC 25923) and Gram-negative (Escherichia coli ATCC 25,922 and Salmonella enterica Typhi ATCC 14023) bacteria, which are relevant in food bacterial contamination. The strains were maintained as glycerol stocks at $-80^{\circ} \mathrm{C}$. All experiments were designed and performed in triplicate.

\subsubsection{Antibacterial Qualitative Assessment-Growth Inhibition}

To qualitatively screen the antibacterial effect of the obtained materials, we utilized an adapted diffusion assay, respecting the general rules exposed in the CLSI 2020 and in our recent study [77]. The obtained $0.5 \mathrm{McF}$ arland bacterial suspensions $\left(1.5 \times 10^{8} \mathrm{CFU} / \mathrm{mL}\right)$, previously prepared in sterile saline $(0.9 \% \mathrm{NaCl}$ solution) were utilized as a standardized inoculum to swab inoculate Petri dishes containing nutritive agar. The obtained materials were cut as discs of $6 \mathrm{~mm}$ diameter and sterilized by UV exposure for $30 \mathrm{~min}$ before use. Sample discs were aseptically placed on the inoculated Petri dishes and these were incubated for $20 \mathrm{~h}$ at $37^{\circ} \mathrm{C}$. After incubation, the diameter of growth inhibition developed around each material specimen was measured and expressed in $\mathrm{mm}$.

\subsubsection{Evaluation of the Planktonic Development of Microorganisms}

Planktonic growth in the presence of the obtained materials was analyzed in nutritive broth. Specimens of $6 \mathrm{~mm}$ in diameter were placed in sterile 24-well plates. Then, $1 \mathrm{~mL}$ of nutritive broth and $10 \mu \mathrm{L}$ of the previously obtained $0.5 \mathrm{McF}$ arland bacterial suspensions in PBS were added. Specimens were allowed to incubate for $24 \mathrm{~h}$ at $37^{\circ} \mathrm{C}$. To spectrophotometrically evaluate the growth of planktonic (free-floating) cultures, $150 \mu \mathrm{L}$ of the obtained bacterial culture were transferred to 96-well plates and the absorbance at $600 \mathrm{~nm}$ was evaluated.

\subsubsection{Monospecific Biofilm Development}

The antibiofilm efficiency was established by transferring specimens (sterile, $6 \mathrm{~mm}$ in diameter) in sterile 24-well plates containing $1 \mathrm{~mL}$ nutritive broth, followed by the inoculation of $10 \mu \mathrm{L}$ of bacterial suspension of $0.5 \mathrm{McF}$ arland standard density. The as prepared plates were incubated for $24 \mathrm{~h}$ at $37^{\circ} \mathrm{C}$. Afterwards the samples were gently 
washed with $1 \mathrm{~mL}$ of sterile saline. In the end, the samples were transferred in $1.5 \mathrm{~mL}$ centrifuge tubes, in $1000 \mu \mathrm{L}$ sterile saline solution. The as obtained samples were then vortexed for $30 \mathrm{~s}$ to ensure the detachment of biofilm cells in suspension. After this, serial 10 fold dilutions were obtained and then inoculated on nutrient agar in order to evaluate the viable colony formation, expressed as CFU (colony forming units) $/ \mathrm{mL}$.

\subsection{Preliminary Tests of AZ1-AZ4 Films as Packaging Material for Cheese}

Cheese samples ( cubic shape with size of $2 \mathrm{~cm})$ were packed in alginate and AZ1AZ4 films and placed in a refrigerator $\left(4{ }^{\circ} \mathrm{C} \pm 1{ }^{\circ} \mathrm{C}\right.$ and $75 \%$ relative humidity) for 14 days. Samples were taken out at 1, 4, 7, 10 and 14 days for the weight loss test. Weight loss was monitored by measuring the weight change of each sample and was calculated as percentage lost from the initial mass.

\subsection{Statistical Analysis}

The obtained results were statistically analyzed using the analysis of variance (ANOVA) performed with Microsoft Excel 2016 (Microsoft Corp., Redmond, WA, USA), having installed XLSTAT 2020.5.1 add-on. The Shapiro-Wilk test was used to check the normal distribution of the data; by Levene's test we assessed the homoscedasticity of the residuals; the results were compared by Tukey's (HSD) test so that the pairs of films that differed in terms of statistical significance were revealed (where $p<0.05$ ).

\section{Results and Discussion}

\subsection{Alginate Films Characterization}

The films were transparent to light yellow from the interaction between alginate, $\mathrm{ZnO}$ nanoparticles and CEO. The transparency of the films decreases with the increase of $\mathrm{ZnO}$ quantity. In the same series the color intensifies to light yellow (Figure 1).

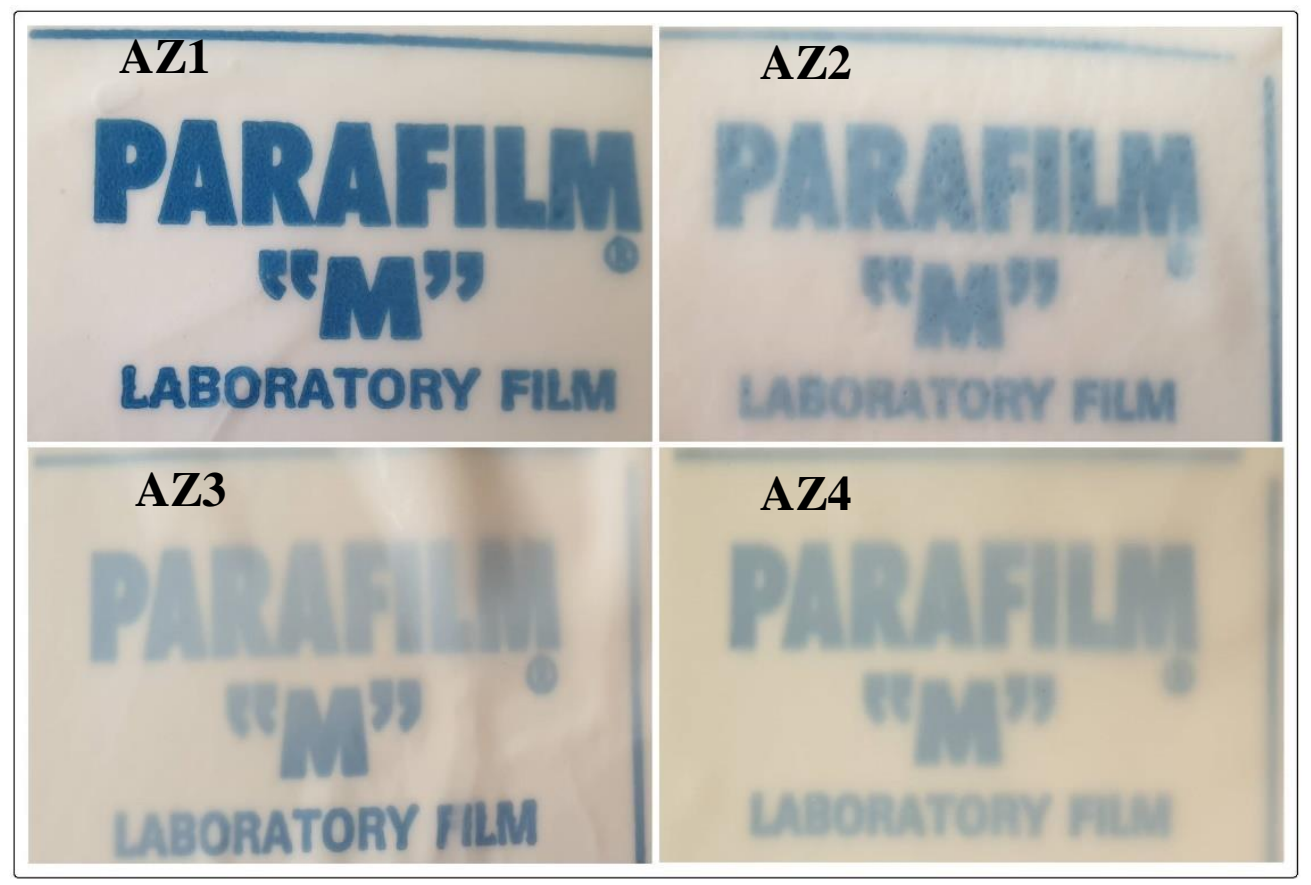

Figure 1. The transparency for AZ1-AZ4 films.

The $\mathrm{ZnO}$ nanoparticles act as a reinforcing agent for the alginate films and at the same time will arrange the alginate polymeric chains in a more orderly manner. The submerging of alginate/ $\mathrm{ZnO} / \mathrm{CEO}$ films in $\mathrm{CaCl}_{2}$ solution will allow calcium ions to penetrate the films and according to the egg-box model [78] to self-assemble the polymeric chains (Figure 2). 


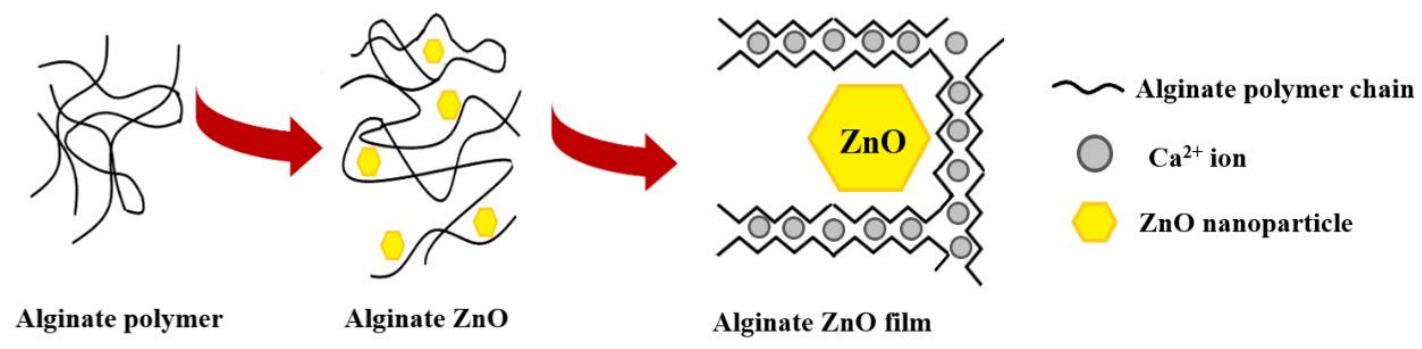

Figure 2. The schematic structure of alginate- $\mathrm{ZnO}$ films. The presence of $\mathrm{ZnO}$ nanoparticles arranges the alginate polymer chains around them. The addition of calcium ions further strengthens the films according to egg-box model.

Similar samples from all films were analyzed by means of UV-Vis, PL, FTIR, TG/DSC, SEM and antibacterial activity was determined.

\subsection{UV-Vis and PL Spectrometry}

\subsubsection{UV-Vis Spectrometry}

The films were light yellow from the interaction between alginate with $\mathrm{ZnO}$ nanoparticles and CEO. The absorption spectra of AZ1-AZ4 films are more complex than the spectra of the individual alginate and $\mathrm{ZnO}$, indicating an interaction degree between the components. The absorption spectrum for the $\mathrm{ZnO}$ nanoparticles is presented in Figure 3a while the spectra for film samples A, AZ1-AZ4 are presented in Figure 3b. Both, the alginate and the $\mathrm{ZnO}$, present $\mathrm{UV}$ absorption bands, with maximum at 212, 271 and $366 \mathrm{~nm}$, respectively. Thus, the spectra for the AZ1-AZ4 films present a broad absorption band in the UV region, due to overlapping of individual spectra. This indicates that the films will present a robust UV shielding performance.
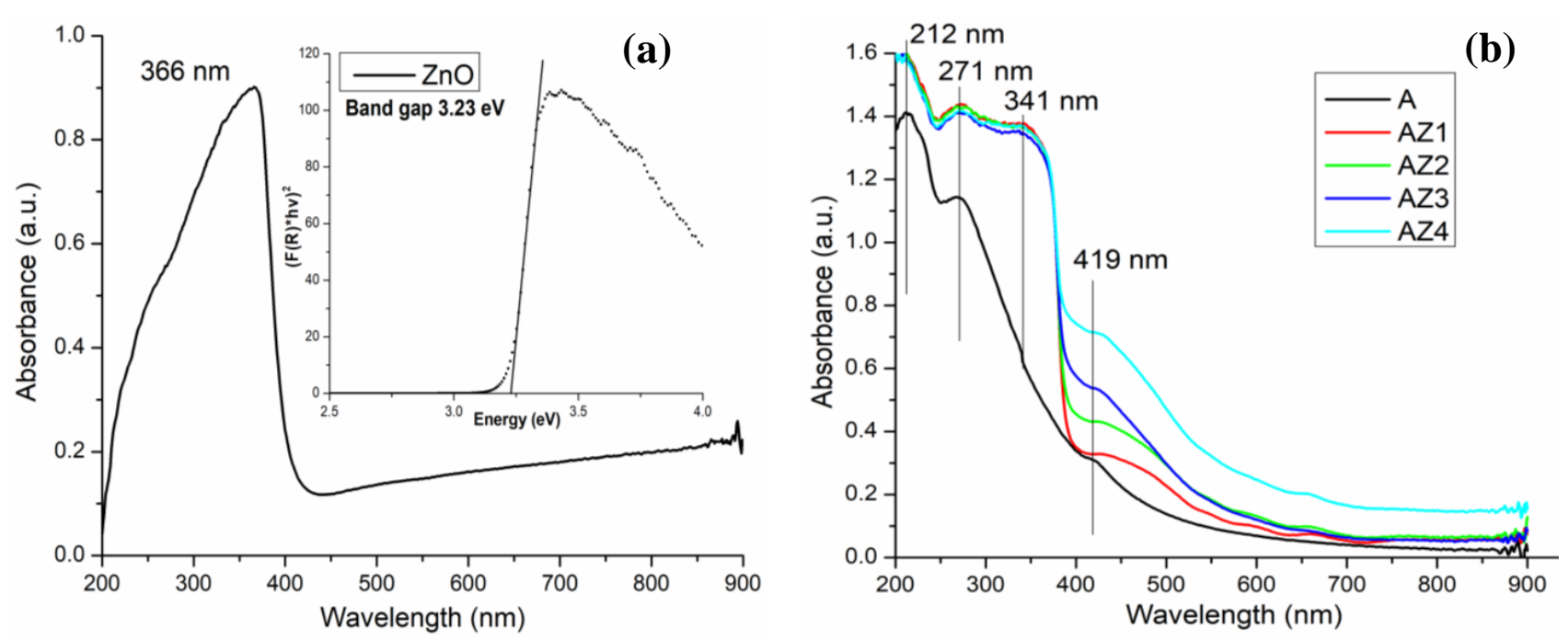

Figure 3. The UV-Vis spectra for $\mathrm{ZnO}$ nanoparticles (a), alginate A and AZ1-AZ4 films (b).

In the visible part of spectrum, at $419 \mathrm{~nm}$, there is an absorption band, which increases in intensity as the $\mathrm{ZnO}$ nanoparticles content increases. This indicates the presence of alginate- $\mathrm{ZnO}$ interactions, as bare $\mathrm{ZnO}$ is white, with no visible absorption bands. This band is responsible for the increasing yellowish color of the films as $\mathrm{ZnO}$ content increases.

The small absorption band at $659 \mathrm{~nm}$ is due to the presence of citronella essential oil.

In conclusion, the films are suitable as UV barrier due to their good absorption in the UV region. The transmittance for AZ1-AZ4 films is under $5 \%$ in the $200-360 \mathrm{~nm}$ interval and under $10 \%$ in the $360-380 \mathrm{~nm}$ interval. The packaging must help preserve the organoleptic properties of the food and provide a longer shelf life. Retarding the lipid 
oxidation can be done by blocking the high energy wavelengths, and therefore the UV barrier property is very important in case of packaging films [79].

Due to the incorporation of ZnO NPs and CEO all the composite films have higher absorbance in the visible domain when compared with control alginate film and therefore an increased opacity $[76,80]$. This is similar to other reported composites with high $\mathrm{ZnO}$ NPs content [81]. AZ4 film has the lower transmittance $(\sim 18 \%$ at $400 \mathrm{~nm}$, increasing to $\sim 71 \%$ at $800 \mathrm{~nm})$ while AZ1 film has the highest visible transmittance $(\sim 45 \%$ at $400 \mathrm{~nm}$, increasing to $\sim 88 \%$ at $800 \mathrm{~nm}$ ). In food preservation the light barrier is also important as a way to reduce photo-oxidation of various organic compounds and degradation of vitamins or nutrients [82]. The calculated opacity values are between 0.39 and 0.85 (Table 2). These values indicate that the films are rather transparent [83], but the opacity is increasing with nanoparticles content.

Table 2. Transmittance at 200-800 nm, thickness (mm) and opacity for alginate (A) and alginate/ZnO/CEO (AZ1-AZ4) films.

\begin{tabular}{|c|c|c|c|c|c|c|c|c|c|}
\hline \multirow{2}{*}{ Sample } & \multicolumn{7}{|c|}{ Transmittance (\%) } & \multirow{2}{*}{ Thickness (mm) } & \multirow{2}{*}{ Opacity } \\
\hline & $200 \mathrm{~nm}$ & $300 \mathrm{~nm}$ & $400 \mathrm{~nm}$ & $500 \mathrm{~nm}$ & $600 \mathrm{~nm}$ & $700 \mathrm{~nm}$ & $800 \mathrm{~nm}$ & & \\
\hline $\mathrm{A}$ & 4.42 & 10.87 & 45.76 & 72.74 & 85.27 & 91.07 & 94.09 & $0.25 \pm 0.02$ & $0.28 \pm 0.02^{a}$ \\
\hline AZ1 & 2.50 & 4.06 & 44.60 & 59.16 & 79.79 & 88.27 & 87.67 & $0.24 \pm 0.06$ & $0.39 \pm 0.09^{a, b}$ \\
\hline AZ2 & 2.44 & 4.01 & 34.98 & 50.76 & 73.84 & 85.11 & 85.95 & $0.30 \pm 0.07$ & $0.45 \pm 0.09^{b}$ \\
\hline AZ3 & 2.60 & 4.27 & 26.52 & 50.34 & 75.75 & 86.45 & 88.42 & $0.24 \pm 0.03$ & $0.50 \pm 0.06^{b}$ \\
\hline $\mathrm{AZ4}$ & 2.35 & 4.16 & 18.08 & 33.72 & 56.58 & 68.21 & 70.86 & $0.29 \pm 0.03$ & $0.85 \pm 0.07^{c}$ \\
\hline
\end{tabular}

Different superscripts $(a, b, c)$ in the last column are significantly different $(p<0.05)$. Values are given as mean \pm SD from triplicate determination.

\subsubsection{PL Spectrometry}

The fluorescence spectrum for the $\mathrm{ZnO}$ nanoparticles is presented in Figure 4a while the spectra for film samples A, AZ1-AZ4 are presented in Figure 4b. The fluorescence bands of alginate and $\mathrm{ZnO}$ NPs are combined into a resulting broad, but less intense single emission band, with visible shoulders in the range 390-550 nm, with an asymmetrical tail towards the higher wavelengths. Similar results are reported also in literature [84].
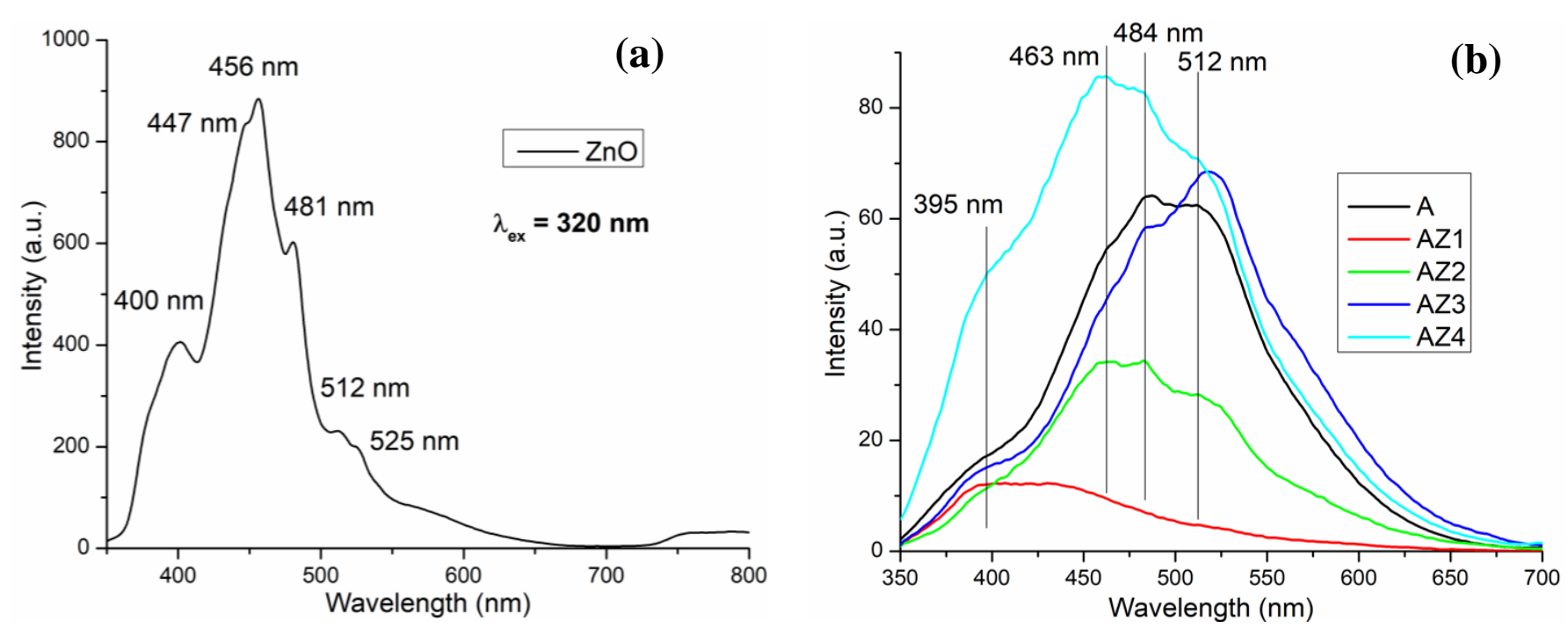

Figure 4. The PL spectra for ZnO nanoparticles (a), alginate A and AZ1-AZ4 films (b).

At low $\mathrm{ZnO}$ content (AZ1 and AZ2 films), the intensity of the fluorescence band of alginate is quenched, the strong $\mathrm{ZnO}$ emission being also blocked by the polymeric film. As $\mathrm{ZnO}$ quantity increases, the fluorescence emission in visible domain for AZ3 and AZ4 samples also present a limited increase. In all the samples, the fluorescence intensity remains much smaller than $\mathrm{ZnO}$ emission, around the alginate's magnitude order. 
This indicates that the interactions between $\mathrm{ZnO}$ and alginate chains are blocking the recombination centers on the nanoparticle's surface, the specific $\mathrm{ZnO}$ fluorescence being diminished. The $\mathrm{ZnO}$ fluorescence spectrum contains two distinct regions. The UV band $(380-400 \mathrm{~nm})$ from the free exciton recombination, and the visible region peaks which arise from various surface defects like oxygen vacancies, zinc vacancies, interstitials and antisites $[18,85]$. The presence of ionic polymeric matrix might offer additional centers for non-radiative recombination ( $a \mathrm{Ca}^{2+}$ and $-\mathrm{COO}^{-}$), which will lead to the decrease of fluorescence intensity.

\subsection{FTIR Spectroscopy and Microscopy \\ 3.3.1. FTIR Spectroscopy}

The modification induced by the $\mathrm{ZnO}$ NPs and $\mathrm{CEO}$ to the polymeric matrix were investigated by FTIR spectroscopy. The principal absorption peaks are presented in Table 3, together with the corresponding assignment. The intense, large band from the interval $3200-3300 \mathrm{~cm}^{-1}$ is due to $\mathrm{O}-\mathrm{H}$ bond vibrations from the alginate [86]. In the presence of $\mathrm{ZnO}$ the new interactions between -OH moieties and nanoparticles' surface, induce small shifts in the peak position [87]. Such shifts were previously reported for alginate-ZnO interactions [88].

Table 3. Assignment of relevant IR absorption bands of alginate (A) and AZ1-AZ4 films.

\begin{tabular}{cccccc}
\hline Sample/Assignment & $\mathbf{A}$ & $\mathbf{A Z 1}$ & $\mathbf{A Z 2}$ & $\mathbf{A Z 3}$ & $\mathbf{A Z 4}$ \\
\hline$v Z n-O$ & & 426 & 427 & 428 & 429 \\
$v_{\mathrm{as}} \mathrm{C}^{-O}-\mathrm{C}$ & 1027 & 1027 & 473 & 467 & 470 \\
$v_{\mathrm{s}} \mathrm{COO}^{-}$ & 1408 & 1408 & 1028 & 1028 & 1027 \\
$v_{\mathrm{as}} \mathrm{COO}^{-}$ & 1600 & 1602 & 1602 & 1409 & 1408 \\
$\mathrm{C}=\mathrm{O}_{\text {group of CEO [41] }}$ & & 1740 & 1737 & 1602 & 1601 \\
vC-H (sat) & 2932 & 2924 & 2920 & 2922 & 1737 \\
vO-H & 3263 & 3273 & 3273 & 3273 & 3275 \\
\hline
\end{tabular}

The peak from $2921 \mathrm{~cm}^{-1}$, attributed to C-H symmetric vibration, remains largely unchanged. Minor shifts can be observed for the peaks attributed to carboxylate symmetric and asymmetric stretching vibrations [89]. The $1027 \mathrm{~cm}^{-1}$ band is attributed to the glyosidic bond of the polysaccharide chain. The intense absorption peaks in the $400-500 \mathrm{~cm}^{-1}$ region are assigned to the presence of $\mathrm{ZnO}$ nanoparticles [90].

\subsubsection{FTIR Microscopy}

By means of FTIR microscopy, we were able to investigate the spatial distribution of $\mathrm{ZnO} N \mathrm{Ns}, \mathrm{CEO}$, and alginate. The FTIR maps corresponding to the strongest absorption peaks at 3275, 1600, and $1030 \mathrm{~cm}^{-1}$ for all five films (AZ1-AZ4 and alginate control) are presented in Figure 5. The seldom small agglomerated clusters/accumulations or defects indicate that distribution of $\mathrm{CEO}$ and $\mathrm{ZnO}$ nanoparticles on the surface of the alginate films is quite homogenous. The maps recorded at 3275 and $1600 \mathrm{~cm}^{-1}$ indicate that the alginate (A) and alginate/ZnO/CEO (AZ1-AZ4) films are quite homogeneous, only minor differences being present, at the level of tens of $\mu \mathrm{m}$ maximum. In the case of AZ3 and AZ4 more important heterogeneities are present as there are some noticeable differences between the maps recorded at 3275, 1600 and $1030 \mathrm{~cm}^{-1}$. This indicates a more heterogeneous distribution of the $\mathrm{CEO}$ and $\mathrm{ZnO}$ nanoparticles within the alginate film. $\mathrm{ZnO}$ can interact with $\mathrm{CEO}$ and a higher amount of $\mathrm{ZnO}$ will promote local agglomeration of nanoparticles and leave less $\mathrm{CEO}$ for emulsion formation. 

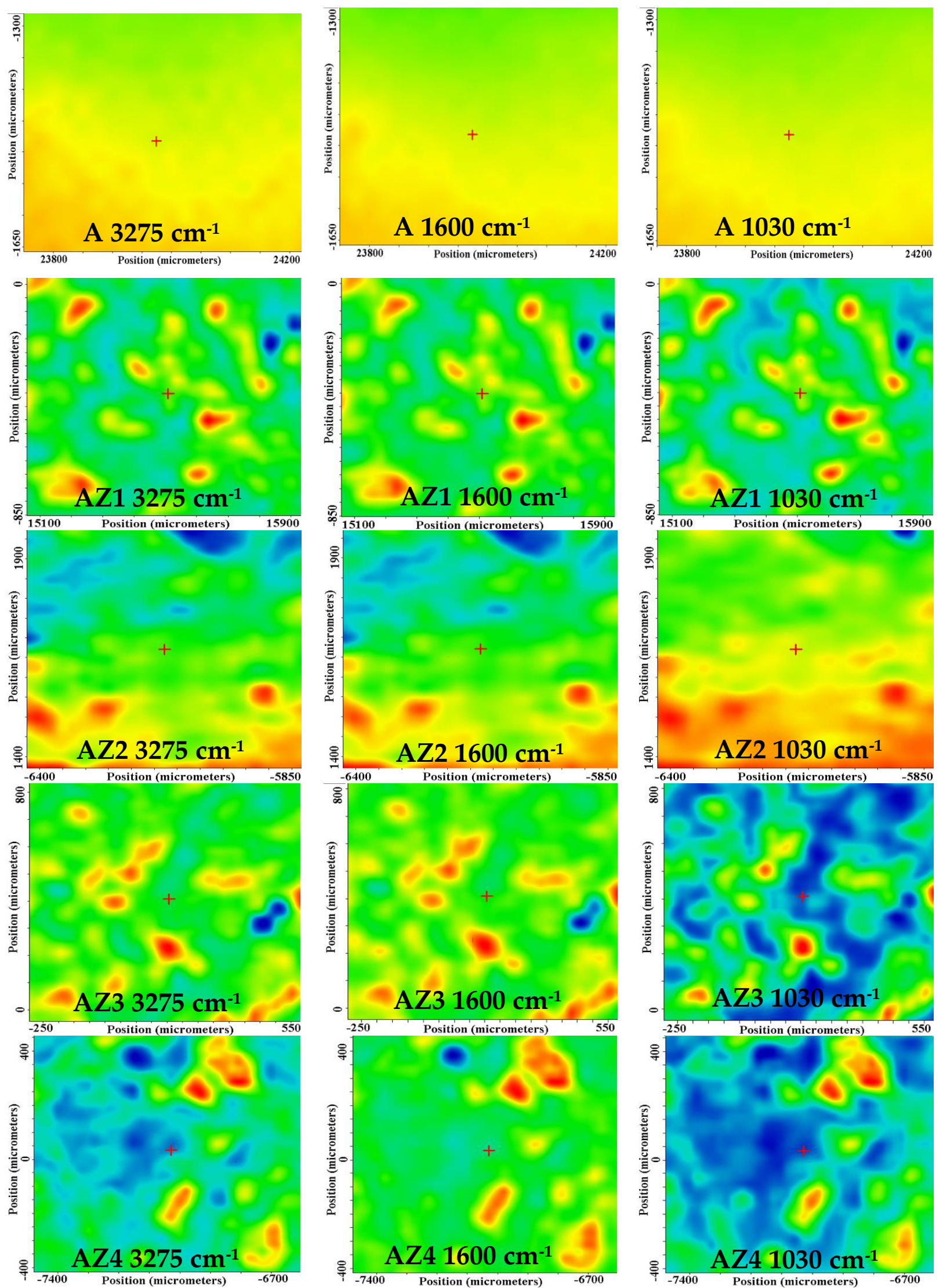

Figure 5. The FTIR maps for alginate (A) and AZ1-AZ4 films at wavenumbers $3275 \mathrm{~cm}^{-1}$ (left column); $1600 \mathrm{~cm}^{-1}$ (middle column); $1030 \mathrm{~cm}^{-1}$ (right column). 


\subsection{Thermal Analysis}

Thermal analysis curves, TG/DSC, for all composite films are presented in Figure 6 and relevant mass loss data are presented in Table 4. The presence of $\mathrm{ZnO}$ nanoparticles in the polymeric films does not substantially modify the thermal stability of the alginate. All AZ1-AZ4 samples start decomposing with $10-15^{\circ} \mathrm{C}$ lower than the alginate control film. In the interval RT $-180^{\circ} \mathrm{C}$ takes place the first degradation phase, in which the samples will be dehydrated and volatile compounds from CEO will be removed [91]. This process is accompanied by a weak endothermic effect on the DSC curve.

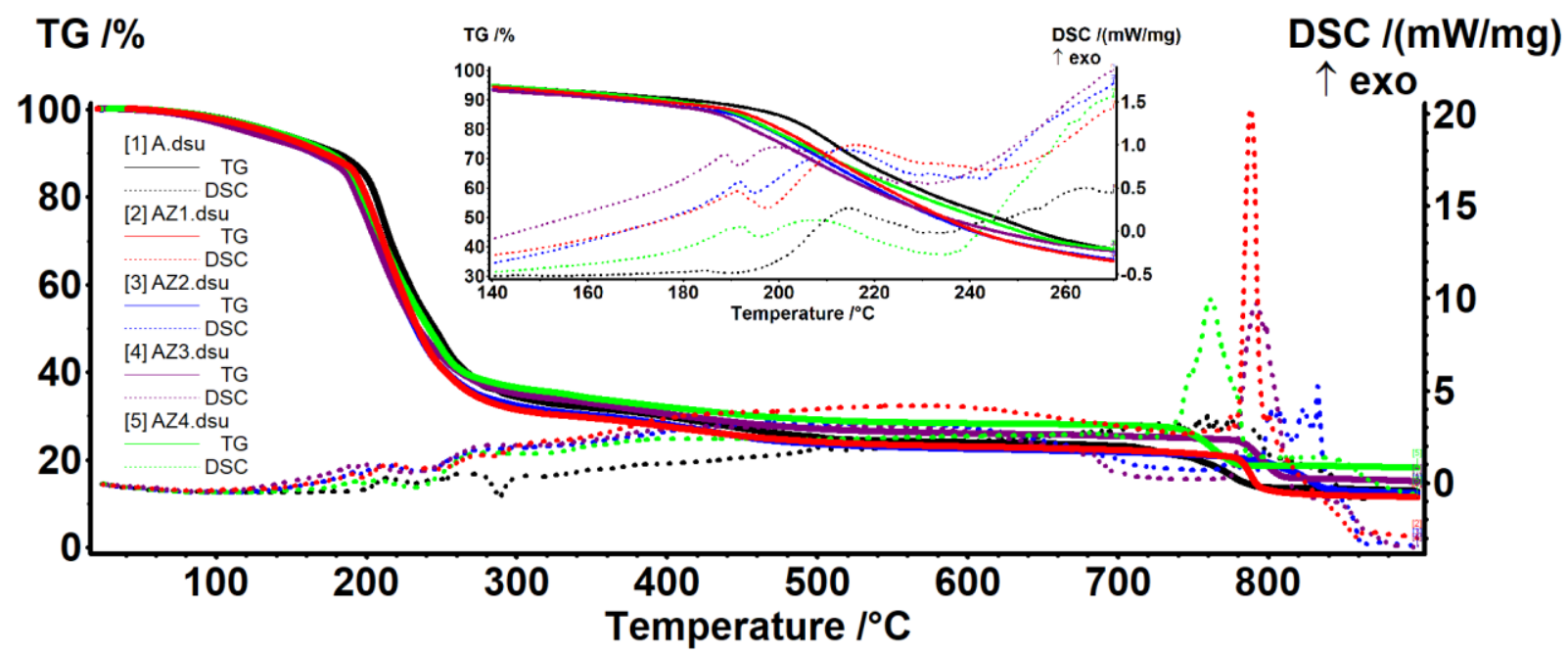

Figure 6. The TG-DSC curves for alginate A and AZ1-AZ4 films.

Table 4. Temperatures at which alginate and AZ1-AZ4 films lost $10 \%, 20 \%, 30 \%, 40 \%$, or $50 \%$ of initial mass.

\begin{tabular}{ccccccc}
\hline Sample & $\mathbf{T}_{\mathbf{1 0}}$ & $\mathbf{T}_{\mathbf{2 0}}$ & $\mathbf{T}_{\mathbf{3 0}}$ & $\mathbf{T}_{\mathbf{4 0}}$ & $\mathbf{T}_{\mathbf{5 0}}$ & Residual Mass \\
\hline A & 180 & 207 & 216 & 229 & 245 & $12.77 \%$ \\
AZ1 & 171 & 200 & 211 & 222 & 235 & $11.37 \%$ \\
AZ2 & 165 & 198 & 209 & 220 & 233 & $12.28 \%$ \\
AZ3 & 165 & 194 & 206 & 219 & 235 & $15.01 \%$ \\
AZ4 & 176 & 198 & 211 & 225 & 242 & $18.15 \%$ \\
\hline
\end{tabular}

The degradative-oxidative processes of organic part take place between 180 and $280^{\circ} \mathrm{C}$ when weak exothermic effects are presented on DSC curves, low molecular weight fractions, and side chain moieties being eliminated [92]. This process may be associated with breakdown of $\mathrm{C}=\mathrm{O}$ and $\mathrm{C}-\mathrm{C}$ bonds from alginate chain and progressive carbonization of polysaccharide molecules [9]. Over $700{ }^{\circ} \mathrm{C}$, the carbonaceous residue is oxidized [4], with the process being accompanied by a strong, sharp exothermic effect. At the same time, due to its inert nature vs. oxidative atmosphere, the residual mass is composed mainly from $\mathrm{ZnO}$ and, therefore, the highest value is for $\mathrm{AZ} 4$ film.

By comparing the temperatures at which the samples lost $10-50 \%$ of initial mass, a better stability can be observed for AZ4 film for most temperature intervals. The literature reports similar findings, with $\mathrm{ZnO}$ and $\mathrm{TiO}_{2}$ nanoparticles not influencing dramatically the thermal stability of the alginate films [9].

The evolved gases from thermal analysis were further analyzed by FTIR to obtain a complex 3D chromatogram (Figure 7). It can be observed that at low temperatures, under $200{ }^{\circ} \mathrm{C}$, components of CEO are eliminated from the samples (peaks at 3080, 2972 and $2926 \mathrm{~cm}^{-1}$ corresponding to the $\mathrm{sp}^{2}$ and $\mathrm{sp}^{3} \mathrm{C}-\mathrm{H}$ stretching vibrations, peak from $2725 \mathrm{~cm}^{-1}$ attributed to the terminal aldehydic C-H and peak at $1740 \mathrm{~cm}^{-1}$ attributed 
to $\mathrm{C}=\mathrm{O}$ stretch) [93]. This indicates that some part of $\mathrm{CEO}$ is incorporated as it is in the alginate polymeric matrix.
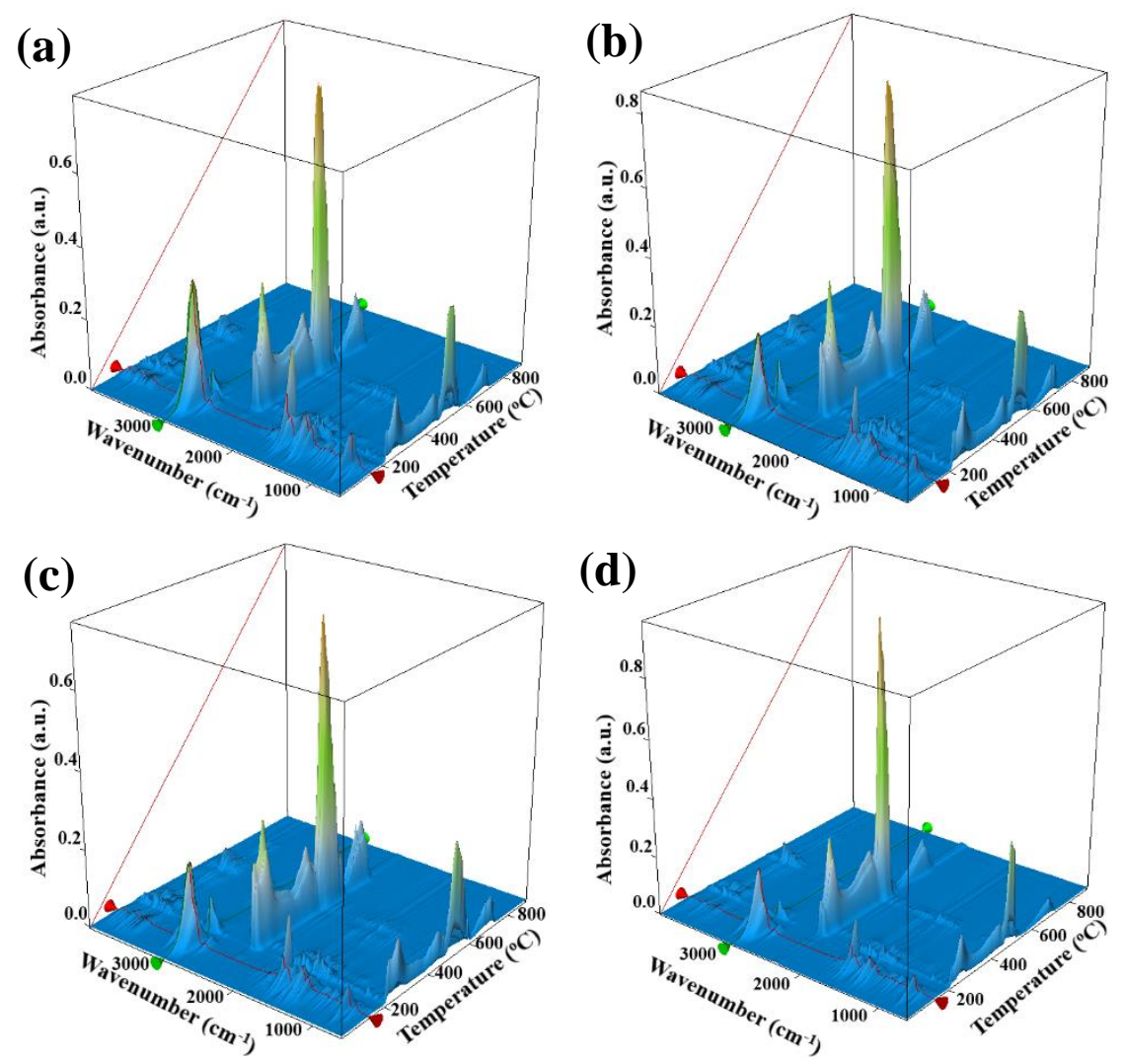

Figure 7. The 3D FTIR chromatogram for the evolved gases during thermal analysis for AZ1 (a); AZ2 (b); AZ3 (c); AZ4 (d) films.

Right after $200{ }^{\circ} \mathrm{C}$ components from CEO are detected again, but in smaller quantities. This indicates that by increasing the temperature the adsorbed CEO from the ZnO NPs surface begins to be eliminated. As temperature increases further any remaining CEO will be degraded together with the alginate matrix by the oxidative atmosphere.

\subsection{Scanning Electron Microscopy (SEM)}

The films' surface morphology was investigated by analyzing the SEM images. At the same time, the energy dispersive spectrum analysis (EDS) can provide a sharp picture of the homogeneity degree of each film sample, presence of local agglomerates and nanoparticles distribution. The distribution of each element $(\mathrm{C}, \mathrm{O}$ and $\mathrm{Zn})$ was determined with the help of the corresponding $\mathrm{K} \alpha$ line from the $\mathrm{X}$-ray spectra.

The EDS mapping images (Figure 8) indicate that the samples are rather homogenous, with some local agglomeration of nanoparticles occurring especially as the $\mathrm{ZnO}$ content increases. This confirms the FTIR map data about the higher inhomogeneity of AZ4 film. 


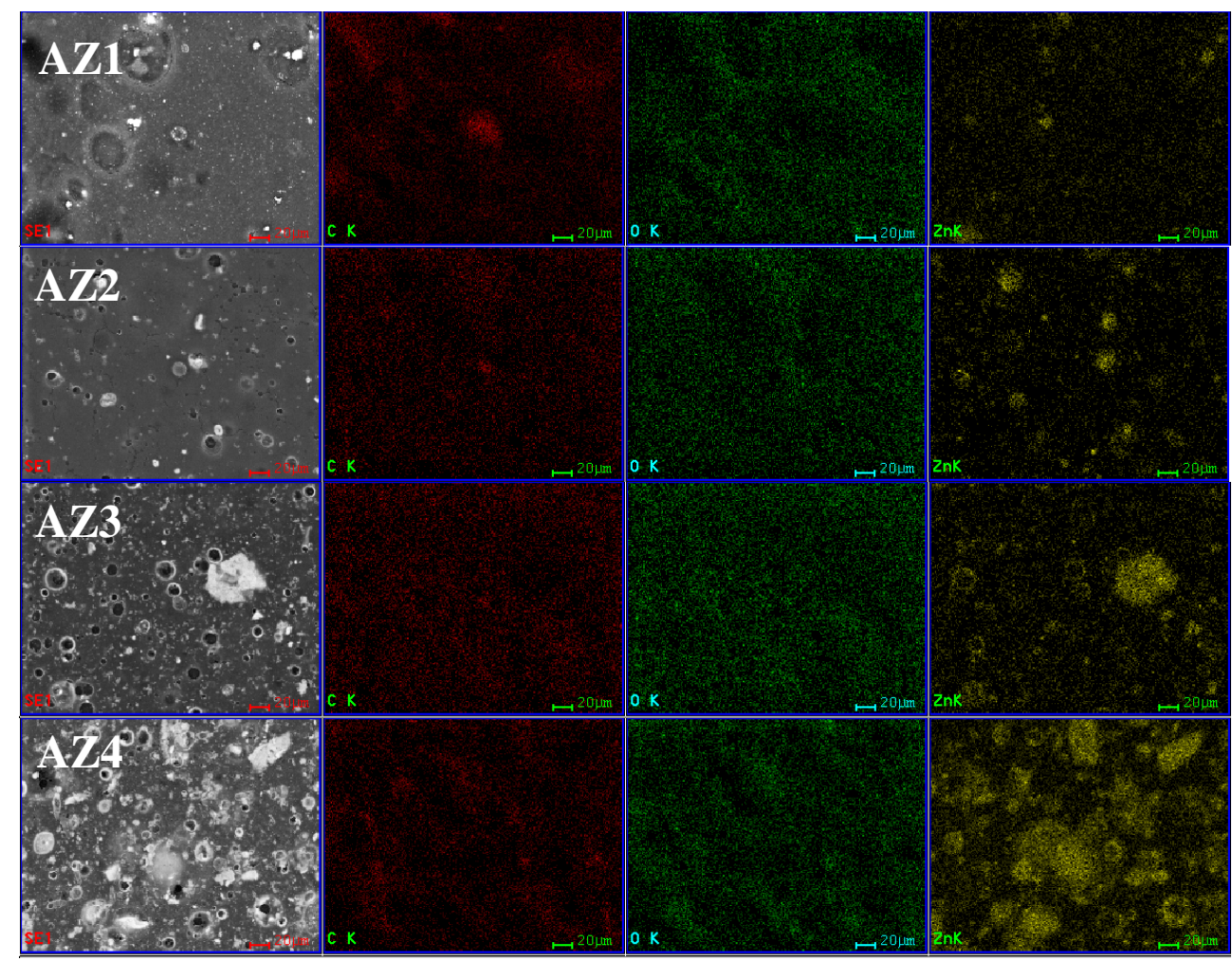

Figure 8. The EDS mapping images for AZ1, AZ2, AZ3, and AZ4 films (elemental distribution for $\mathrm{C}$-red, $\mathrm{O}$ - green and $\mathrm{Zn}$-yellow).

The SEM images for the alginate control film, Figure 9, present a uniform surface. Higher magnifications indicate the presence of some minor defects, like pores. For the AZ1-AZ4 films containing alginate/ZnO/CEO, the SEM images are also presented in Figure 9. The SEM images indicate the presence of some pores on the surface of all films. The size of the pores decreases as the $\mathrm{ZnO}$ amount increases, most probably because the $\mathrm{ZnO}$ nanoparticles adsorb the $\mathrm{CEO}$ better and there are smaller quantities of oil to form the emulsion in alginate solution. When $\mathrm{ZnO}$ amount is small, there are many droplets of CEO in the alginate solution, which can coalescence to form larger pores on the film surface. Consequently, the pore size decreases when $\mathrm{ZnO}$ amount increases. The large size pores are presented on the AZ1 film, while for the AZ2 sample the pore size decreases sharply to smaller diameters, even less than $5 \mu \mathrm{m}$, but with a homogeneous distribution. The water vapor permeability measurements indicate a better performance for the films with higher $\mathrm{ZnO}$ content. As the pores observed on the surface, in the SEM images, are not connected and do not cross the membrane it seems that their influence is negligible. At the same time, the increasing amount of $\mathrm{ZnO}$ leads to denser membranes, with lower permeability. The higher magnification SEM images (50-100 k X) reveal the presence of $\mathrm{ZnO}$ nanoparticle agglomerates in the alginate film structure, with sizes in the $48-89 \mathrm{~nm}$ interval (right column images from Figure 9). 

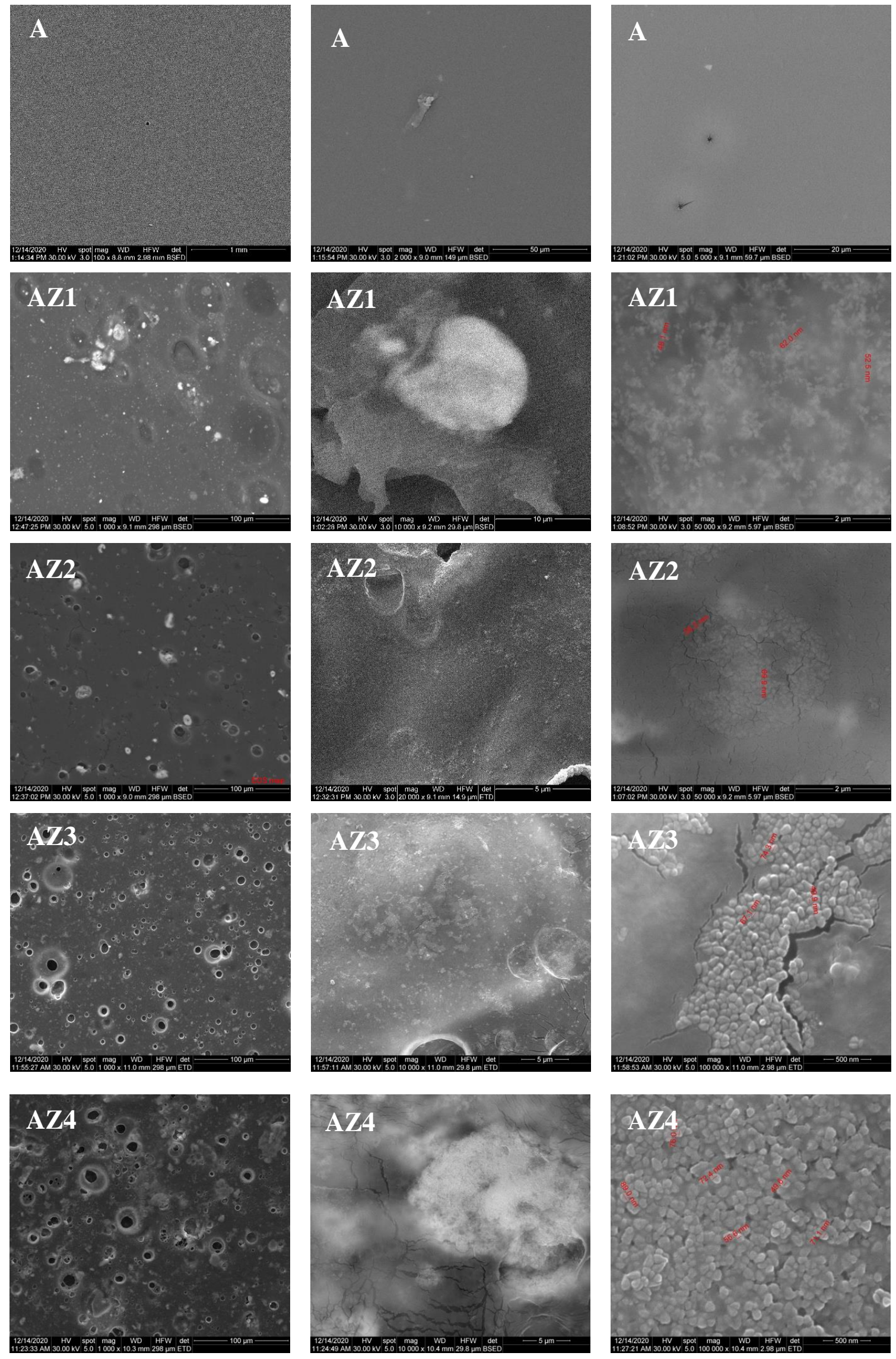

Figure 9. The SEM images for alginate A, AZ1-AZ4 films. On the right column, the ZnO nanoparticles were measured (red numbers). 


\subsection{Water Vapor Permeability (WVP)}

Ideally, loss of water, flavor and other specific substances should be negligible through packaging films for food [92]. Water vapor permeability (WVP) values are important as it controls the moisture migration between food and the outside of packaging. Usually microbial spoilage of food can be associated also with a high value for WVP.

The obtained values for WVP determination are presented in Table 5. The WVP value for the alginate control (A) film is average when compared with literature [92,94] due to addition of glycerol, as this will form hydrogen bonds with the base polymer, which further increase the chain-chain distance [95]. Nevertheless, important decreases in WVP are observed for all samples when compared with alginate control film. The high decrease between A and AZ1 can be explained by the presence of both CEO and ZnO. CEO has a clear hydrophobic nature and therefore will act towards decreasing of WVP, similar findings being reported [13].

Table 5. Water vapor permeability (WVP) for control alginate (A) and AZ1-AZ4 films.

\begin{tabular}{cc}
\hline Film Code & WVP (10-10 $\mathbf{g} / \mathbf{P a} \cdot \mathbf{m} \cdot \mathbf{s})$ \\
\hline A (alginate control) & $5.718 \pm 0.011^{\mathrm{a}}$ \\
AZ1 & $4.542 \pm 0.018^{\mathrm{b}}$ \\
AZ2 & $4.126 \pm 0.023^{\mathrm{c}}$ \\
AZ3 & $3.687 \pm 0.056^{\mathrm{d}}$ \\
AZ4 & $3.043 \pm 0.086^{\mathrm{e}}$ \\
\hline
\end{tabular}

Different superscript letters indicate statistically significant differences between films $(p<0.05)$.

The presence of $\mathrm{ZnO}$ nanoparticles also act as a physical barrier, increasing the pathways for water molecules [5,92]. The values for WVP decreased as the content of ZnO NPs increased. This decrease of WVP values can be due to the formation of $\mathrm{ZnO}$-alginate composite structure, in which tighter and denser arrangements appear, with $\mathrm{ZnO}$ nanoparticles being impermeable to water. As such, the water has a more complicated, longer pathway through these composite films, as presented in Figure 10.
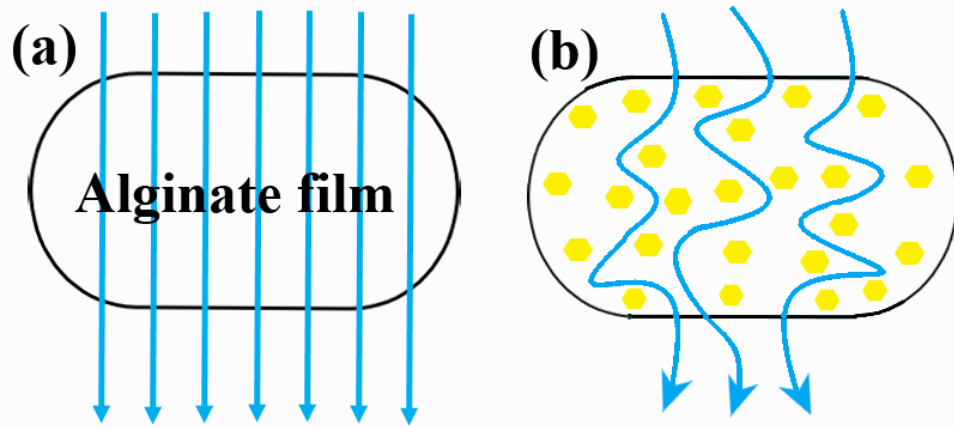

\section{$\mathrm{ZnO}$}

Figure 10. The proposed mechanism behind decrease of WVP values for AZ1-AZ4 films. Water pathway through the Alginate film (a) and through AZ1-AZ4 films (b).

Further decrease of WVP values for AZ2-AZ4 films, as $\mathrm{ZnO}$ amount increases, confirms the influence of mineral nanoparticles. The increase in $\mathrm{SD}$ values can also be ascribed to the increasing presence of local agglomeration of nanoparticles, which equals with decreasing homogeneity, as seen in SEM images.

A higher value for WVP can be expected from a porous structure, when the pores are connected. As the SEM micrographs indicate, the AZ1-AZ4 films have a porous surface, but the pores are not connected and do not cross the membrane. 


\subsection{Swelling Study}

The swelling studies were carried out in both water and PBS $(\mathrm{pH}=7.4)$. The obtained data, Table 6, indicate a decrease of the swelling capacity with the increase of $\mathrm{ZnO}$ content in the alginate film.

Table 6. Swelling percentage for the alginate and AZ1-AZ4 films over $48 \mathrm{~h}$.

\begin{tabular}{ccccccc}
\hline \multirow{2}{*}{ Sample } & \multicolumn{7}{c}{ Water PBS } \\
\cline { 2 - 7 } & $\mathbf{0 . 5} \mathbf{h}$ & $\mathbf{1 ~ h}$ & $\mathbf{2} \mathbf{h}$ & $\mathbf{3} \mathbf{h}$ & $\mathbf{2 4} \mathbf{h}$ & $\mathbf{4 8} \mathbf{h}$ \\
\hline \multirow{2}{*}{$\mathrm{A}$} & $552.29 \%$ & $578.36 \%$ & $596.51 \%$ & $616.29 \%$ & $600.99 \%$ & $590.38 \%$ \\
& $539.12 \%$ & $652.05 \%$ & $701.89 \%$ & $719.90 \%$ & $742.41 \%$ & $739.26 \%$ \\
\multirow{2}{*}{ AZ1 } & $516.83 \%$ & $536.86 \%$ & $537.98 \%$ & $550.79 \%$ & $538.94 \%$ & $534.39 \%$ \\
& $604.69 \%$ & $704.03 \%$ & $745.48 \%$ & $756.20 \%$ & $789.36 \%$ & $672.18 \%$ \\
AZ2 & $484.78 \%$ & $477.38 \%$ & $528.66 \%$ & $542.09 \%$ & $522.53 \%$ & $528.36 \%$ \\
& $456.87 \%$ & $634.35 \%$ & $708.18 \%$ & $723.69 \%$ & $762.62 \%$ & $750.84 \%$ \\
AZ3 & $427.03 \%$ & $450.41 \%$ & $417.68 \%$ & $434.96 \%$ & $421.95 \%$ & $427.24 \%$ \\
& $360.64 \%$ & $530.95 \%$ & $640.04 \%$ & $655.10 \%$ & $703.20 \%$ & $688.63 \%$ \\
AZ4 & $297.27 \%$ & $342.73 \%$ & $379.77 \%$ & $398.08 \%$ & $394.69 \%$ & $354.96 \%$ \\
& $282.05 \%$ & $374.36 \%$ & $595.63 \%$ & $659.27 \%$ & $741.75 \%$ & $684.43 \%$ \\
\hline
\end{tabular}

The AZ1-AZ4 films presented a lower water uptake capacity, as the $\mathrm{ZnO}$ amount in each composition increases. The proposed mechanism is presented in Figure 11. As more $\mathrm{ZnO}$ nanoparticles are present in the $\mathrm{AZ}$ films, the alginate chains will interact with them, and will lock them in closer positions, with smaller gaps available for water molecules. Additionally, as there is an important difference between the water absorption capacity of alginate and $\mathrm{ZnO}$, thus a higher amount of $\mathrm{ZnO}$ will decrease the hydration capacity. Therefore, the swelling capacity will decrease with the increase of $\mathrm{ZnO}$ nanoparticles number. These results are in agreement with the WVP data.

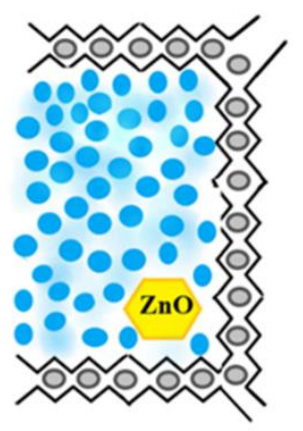

(a)

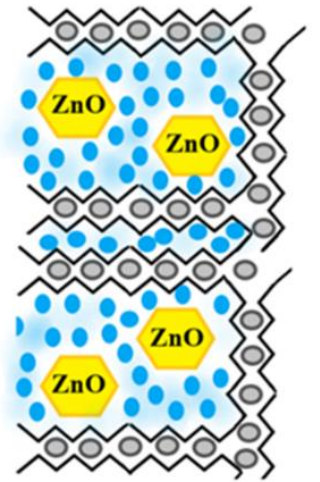

(b)

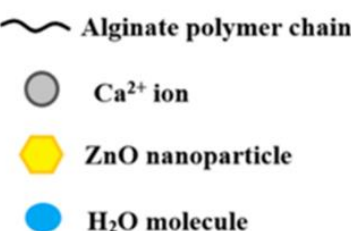

$\mathrm{H}_{2} \mathrm{O}$ molecule

Figure 11. The swelling process for alginate-ZnO and CEO films (AZ1-AZ4). Films with low $\mathrm{ZnO}$ nanoparticles content can uptake more water (a). Higher $\mathrm{ZnO}$ nanoparticles content will inhibit water uptake, resulting in a lower swelling percentage $(\mathbf{b})$.

All the films presented a fast water uptake, as the close to maximum swelling capacity was obtained after $30 \mathrm{~min}$. The swelling continued to increase slowly for $3 \mathrm{~h}$, but at 24 and $48 \mathrm{~h}$ the mass of the films begins to decrease, the mass loss indicating a possible solubilization of some alginate from the samples.

The values obtained in the PBS swelling study were larger if compared with those obtained in the water swelling study. In addition, the alginate films in PBS start to present noticeable disintegration after $48 \mathrm{~h}$, while those kept in water are keeping their integrity even after 4 weeks. This can be explained by the slow replacing of $\mathrm{Ca}^{2+}$ ions with $\mathrm{Na}^{+}$. As the process advances, the "egg-box" model of calcium-alginate interactions is replaced by 
the simple sodium-alginate formation, which is water soluble. The chains begin to break apart and the films disintegrate.

\subsection{Antibacterial Activity}

The evaluation of the growth inhibition results determined that the AZ1-AZ4 films show a different antibacterial effect, depending on the tested strain and ZnO NPs content. We utilized Gram-positive (S. aureus; B. cereus) and Gram-negative (S. Typhi; E. coli) strains, relevant in foodborne infections, in order to highlight antibacterial coverage of the obtained nanomodified films. The control alginate film presented no antibacterial activity.

Results show that growth inhibition is impaired in a $\mathrm{ZnO}$ concentration manner in all of the investigated strains, the highest values of growth inhibition zones being obtained for AZ4 samples, followed by AZ3, then AZ2 and AZ1. Figure 12 also reveals that the presence of CEO has a synergic antibacterial effect, together with ZnO. Plain CEO shows a lower growth inhibition potential, but this inhibition is increased in $\mathrm{ZnO}$ containing samples. Intriguingly, the $\mathrm{ZnO}$ control samples showed a modest antibacterial effect, this being significant only in B. cereus strain. Therefore, these results suggest that synergistic activity of $\mathrm{CEO}$ and $\mathrm{ZnO}$ is responsible for growth inhibition in evaluated strains (Figure 12).

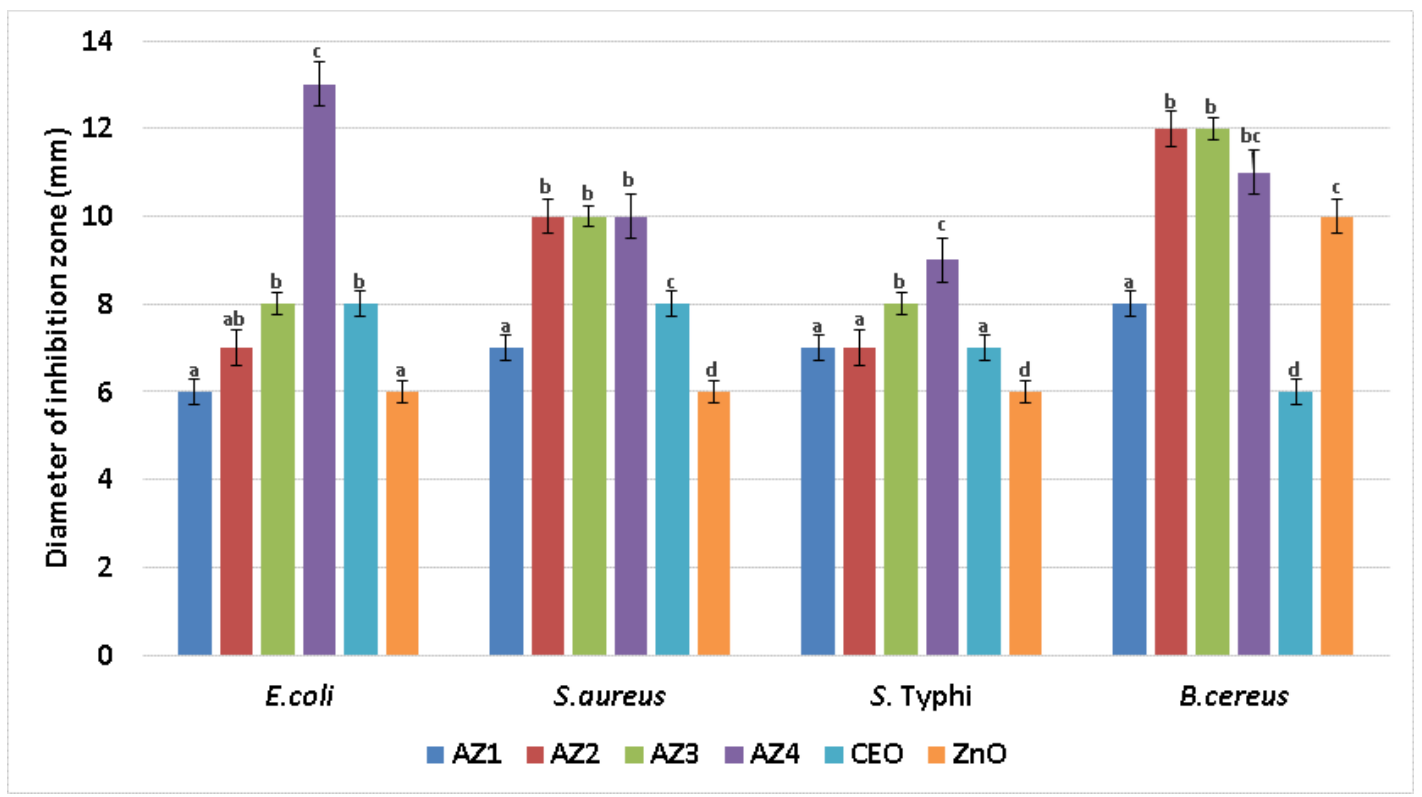

Figure 12. Graphic representation of growth inhibition diameters (shown in $\mathrm{mm}$ ) obtained after the cultivation of evaluated bacterial strains in the presence of alginate and AZ1-AZ4 films. Different small letters indicate statistically significant differences between films $(p<0.05)$.

Planktonic growth inhibition results showed that bioactive compounds (i.e., CEO and $\mathrm{ZnO}$ NPs) could be released from the nanostructured materials, since they affect the development of free-floating cells. Figure 13 reveals that the highest bacterial growth inhibition in nutritive broth is obtained for the samples containing CEO and higher amounts of $\mathrm{ZnO}$ NPs. However, growth inhibition was also obtained for ZnO NPs and CEO controls, but the results are less significant.

Although the initial amount of CEO in the AZ1-AZ4 films is equal, its distribution is not identical. Part of the CEO is loaded on the ZnO NPs surface and the rest is dispersed inside the film thickness as droplets. As the $\mathrm{ZnO}$ NPs content increases, the amount of CEO adsorbed on the nanoparticles surface increases, and the free CEO inside the film decreases. Therefore, while in AZ1 film a larger CEO amount is available from the beginning, in AZ4 film a longer release time for CEO is expected. 


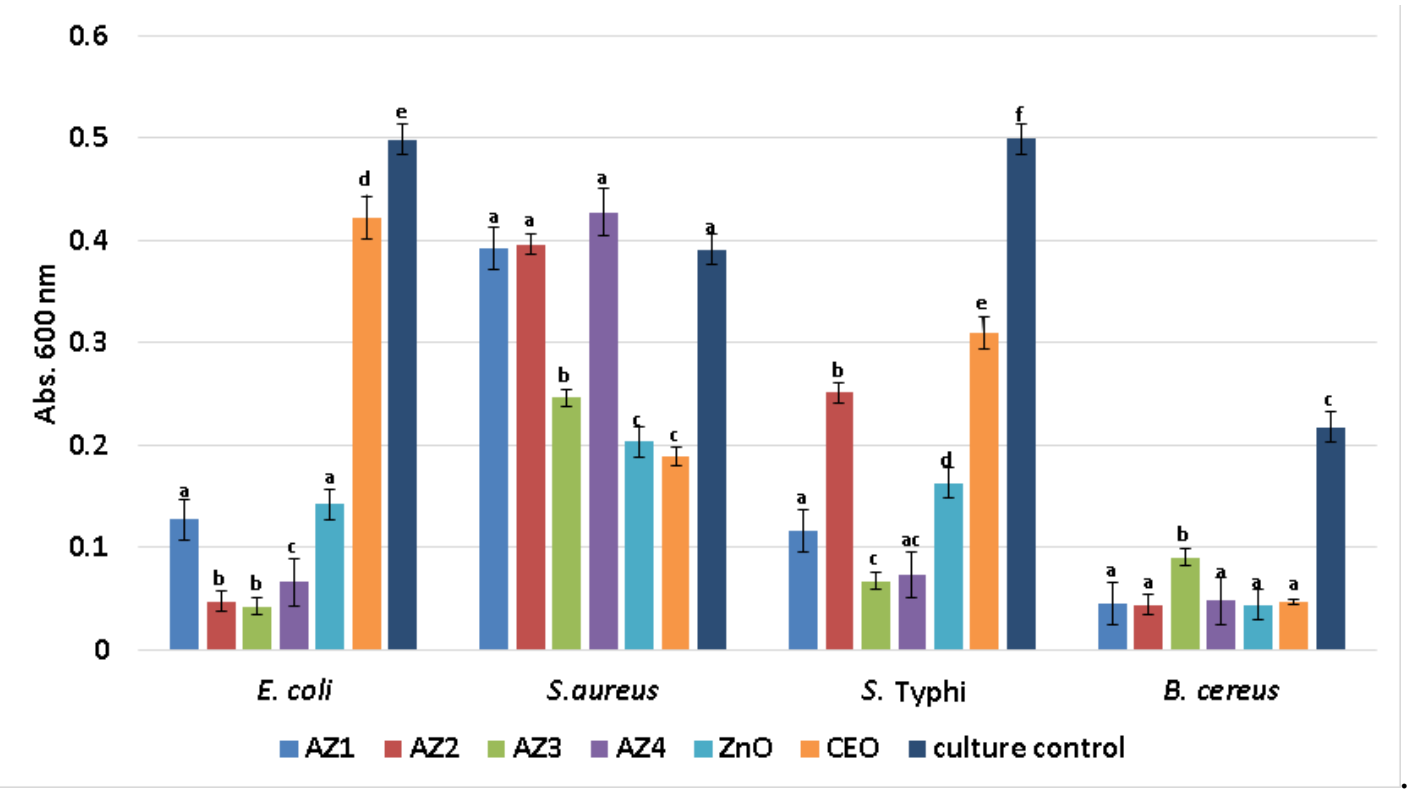

Figure 13. Graphic representation of average absorbances at $600 \mathrm{~nm}$ revealing growth of planktonic bacterial cultures in the presence of control and AZ1-AZ4 films for $24 \mathrm{~h}$ at $37^{\circ} \mathrm{C}$. Different small letters indicate statistically significant differences between films $(p<0.05)$.

Not only the growth of planktonic cells was influenced by the obtained AZ1-AZ4 films, but also their attachment and biofilm development. Our data show biofilms are significantly reduced after $24 \mathrm{~h}$ incubation in samples containing CEO and $\mathrm{ZnO} \mathrm{NPs}$, in a $\mathrm{ZnO}$ NPs concentration dependent manner.

Highest biofilm inhibition was obtained in the presence of AZ4, followed by AZ3 samples, the inhibition being relatively uniform among all tested bacterial isolates (Figure 14). However, the highest antibacterial effect was seen against the Gram-positive B. cereus microorganism, suggesting these coatings may be tailored to target particular types of bacteria, depending on the intended application and on the susceptibility of each strain.

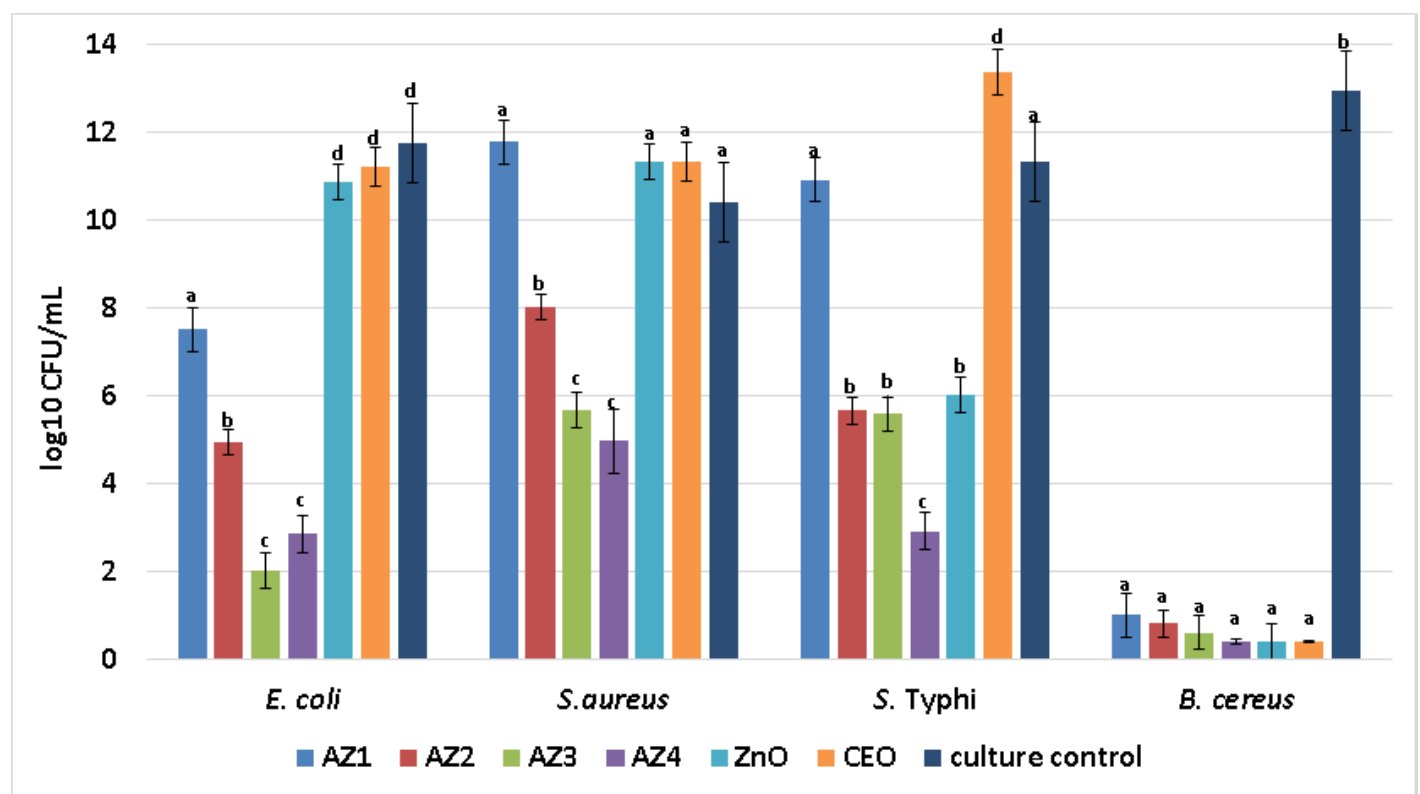

Figure 14. Graphical representation of $\log 10 \mathrm{CFU} / \mathrm{mL}$ values obtained for the tested Gram-positive and Gram-negative bacterial strains, expressing biofilm embedded cells developed on control and AZ1-AZ4 films after $24 \mathrm{~h}$ incubation. Different small letters indicate statistically significant differences between films $(p<0.05)$. 
The literature indicates that CEO is especially effective against Gram-positive bacterial strains like $S$. aureus or $B$. cereus $[96,97]$. At the same time, $\mathrm{ZnO}$ nanoparticles are more potent against $E$. coli than against $S$. aureus $[18,19]$. Nonetheless, our studies reveal that these alginate/ $\mathrm{ZnO} / \mathrm{CEO}$ films have a good antibacterial coverage, the $\mathrm{ZnO}$ nanoparticles and CEO acting synergic, thus being efficient against several pathogens, despite Gramnegative strains being usually more resistant than Gram-positive due to their intrinsic resistance mechanism $[96,98]$.

\subsection{Preliminary Evaluation of AZ1-AZ4 Films as Coatings for Soft Cheese}

Soft cheese was packed in the alginate composite films (containing ZnO NPs loaded with CEO) and was stored at $4{ }^{\circ} \mathrm{C} \pm 1{ }^{\circ} \mathrm{C}$ and $75 \%$ relative humidity (RH) for 14 days. A control lot was packed in the simple alginate film. The preliminary visual quality check (Figure 15) and weight loss data (Table 7) indicates that AZ1-AZ4 films were effective in preserving the cheese.

\section{Control}

1

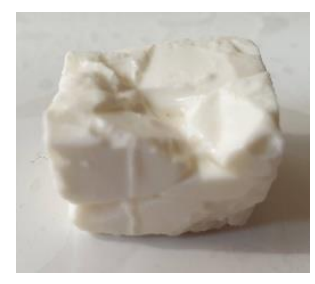

14

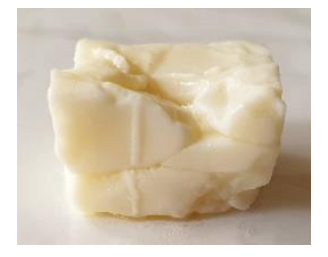

AZ1
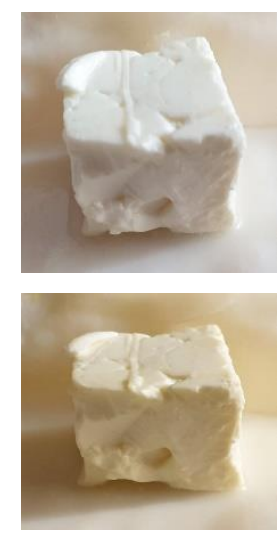

AZ2
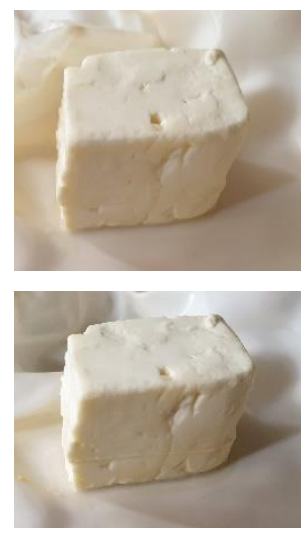

AZ3
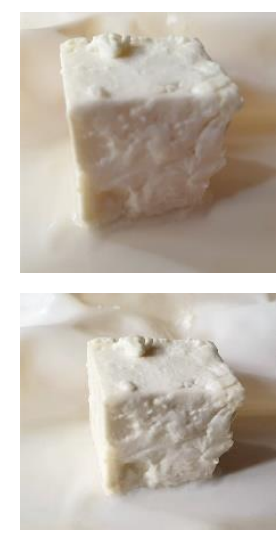

AZ4
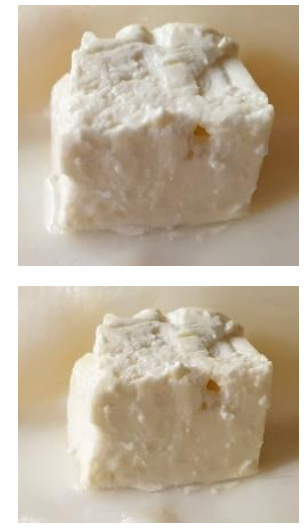

Figure 15. Visual appearance of soft cheese bits packaged in alginate control film and AZ1-AZ4 films, initial and after 14 days storage at $4{ }^{\circ} \mathrm{C}$ and $75 \%$ relative humidity.

Table 7. Weight loss for cheese bits coated with alginate control and AZ1-AZ4 films during storage.

\begin{tabular}{cccccc}
\hline \multirow{2}{*}{ Sample } & \multicolumn{5}{c}{ Weight Loss (\%) } \\
\cline { 2 - 6 } & 1 Day & 4 Days & 7 Days & 10 Days & 14 Days \\
\hline A & $2.01 \pm 0.15^{\mathrm{a}}$ & $8.16 \pm 0.12^{\mathrm{a}}$ & $14.56 \pm 0.16^{\mathrm{a}}$ & $21.21 \pm 0.18^{\mathrm{a}}$ & $30.10 \pm 0.23^{\mathrm{a}}$ \\
$\mathrm{AZ1}$ & $1.81 \pm 0.09^{\mathrm{a}}$ & $7.32 \pm 0.11^{\mathrm{b}}$ & $13.02 \pm 0.12^{\mathrm{b}}$ & $18.91 \pm 0.15^{\mathrm{b}}$ & $26.74 \pm 0.19^{\mathrm{b}}$ \\
AZ2 & $1.27 \pm 0.05^{\mathrm{b}}$ & $5.16 \pm 0.04^{\mathrm{c}}$ & $9.31 \pm 0.07^{\mathrm{c}}$ & $13.70 \pm 0.11^{\mathrm{c}}$ & $19.46 \pm 0.12^{\mathrm{c}}$ \\
AZ3 & $0.86 \pm 0.06^{\mathrm{c}}$ & $3.56 \pm 0.06^{\mathrm{d}}$ & $6.51 \pm 0.10^{\mathrm{d}}$ & $9.50 \pm 0.11^{\mathrm{d}}$ & $13.72 \pm 0.15^{\mathrm{d}}$ \\
AZ4 & $0.33 \pm 0.03^{\mathrm{d}}$ & $1.41 \pm 0.04^{\mathrm{e}}$ & $2.66 \pm 0.08^{\mathrm{e}}$ & $4.11 \pm 0.07^{\mathrm{e}}$ & $6.02 \pm 0.11^{\mathrm{e}}$ \\
\hline
\end{tabular}

Different superscript letters in the same column indicate statistically significant differences between films $(p<0.05)$.

The samples packed in AZ1-AZ4 films were clearly different from the control sample after 14 days. While the control sample was rather hard and translucent with visible signs of spoilage, the AZ1-AZ4 packaged samples were whiter, soft and kept the original creamy texture of the cheese.

The weight loss of the cheese bits increased linearly, in all cases, with storage time, with average values ranged from $2.15 \%$ for control sample to $0.43 \%$ for AZ4 packed sample (Table 7). This is possible because of the continuous water vapor movement from cheese to surrounding environment.

The $\mathrm{pH}$ value of the cheese was monitored daily and was found to be in the interval 4.45-4.57 for all AZ1-AZ4 samples, indicating little to no variation. The quasi constant 
$\mathrm{pH}$ value of the coated cheese is reported previously in literature [99]. However, the $\mathrm{pH}$ of the control sample dropped to 4.33 , probably due to increased fermentation promoted by microorganisms.

\section{Conclusions}

Innovative biodegradable packaging films based on alginate were obtained. The antibacterial activity was ensured by the addition of $\mathrm{ZnO}$ nanoparticles loaded with CEO. The films are transparent, but the opacity increases with the $\mathrm{ZnO}$ content. Even at the highest $\mathrm{ZnO}$ content, the films can be considered homogenous, with no clefts. The presence of $\mathrm{ZnO}$ and $\mathrm{CEO}$ in the alginate films has improved the light and water barrier properties. The antibacterial assay indicates that the inhibition is relatively uniform among all four bacterial tested strains. The best antibacterial activity is reported for B. cereus. Overall the $\mathrm{ZnO}$ and $\mathrm{CEO}$ acts in a synergic way, strongly inhibiting the growth of both Gram-positive and Gram-negative strains. Preliminary test on soft cheese indicates that the samples preserved in AZ1-AZ4 films retained the color, surface texture and softness over 14 days, successfully extending the shelf life, while weight loss decreased as $\mathrm{ZnO}$ content increased. In conclusion, an antibacterial potential packaging for cheese and other foods based on alginate/ $\mathrm{ZnO} / \mathrm{CEO}$ was for the first time obtained and characterized.

Author Contributions: Conceptualization, D.F., A.F. and L.M.; methodology, L.M. and O.O.; formal analysis, R.-D.T., A.M.H. and A.F.; investigation, R.-D.T., A.M.H. and D.F.; resources, E.A.; data curation, L.M.; writing-original draft preparation, L.M. and O.O.; writing-review and editing, A.F.; supervision, D.F.; project administration, E.A.; funding acquisition, O.O. All authors have read and agreed to the published version of the manuscript.

Funding: This work was supported by a grant of the Romanian Ministry of Research and Innovation, CCCDI-UEFISCDI, project number PN-III-P1-1.2-PCCDI-2017-0689/P1. “Lib2Life-Revitalizarea bibliotecilor şi a patrimoniului cultural prin tehnologii avansate" within PNCDI III. The APC was funded by University POLITEHNICA of Bucharest.

Institutional Review Board Statement: Not applicable.

Informed Consent Statement: Not applicable.

Data Availability Statement: Not applicable.

Conflicts of Interest: The authors declare no conflict of interest. The funders had no role in the design of the study; in the collection, analyses, or interpretation of data; in the writing of the manuscript, or in the decision to publish the results.

\section{References}

1. Artiga-Artigas, M.; Acevedo-Fani, A.; Martin-Belloso, O. Improving the shelf life of low-fat cut cheese using nanoemulsionbased edible coatings containing oregano essential oil and mandarin fiber. Food Control. 2017, 76, 1-12. [CrossRef]

2. Motelica, L.; Ficai, D.; Oprea, O.C.; Ficai, A.; Andronescu, E. Smart Food Packaging Designed by Nanotechnological and Drug Delivery Approaches. Coatings 2020, 10, 806. [CrossRef]

3. Lemnaru (Popa), G.-M.; Trusca, R.D.; Ilie, C.-I.; Tiplea, R.D.; Ficai, D.; Oprea, O.; Stoica-Guzun, A.; Ficai, A.; Ditu, L.-M. Antibacterial Activity of Bacterial Cellulose Loaded with Bacitracin and Amoxicillin: In Vitro Studies. Molecules 2020, $25,4069$. [CrossRef]

4. Makaremi, M.; Yousefi, H.; Cavallaro, G.; Lazzara, G.; Goh, C.B.S.; Lee, S.M.; Solouk, A.; Pasbakhsh, P. Safely Dissolvable and Healable Active Packaging Films Based on Alginate and Pectin. Polymers 2019, 11, 1594. [CrossRef]

5. Motelica, L.; Ficai, D.; Ficai, A.; Trusca, R.D.; Ilie, C.I.; Oprea, O.C.; Andronescu, E. Innovative Antimicrobial Chitosan/ZnO/Ag NPs/Citronella Essential Oil Nanocomposite-Potential Coating for Grapes. Foods 2020, 9, 1801. [CrossRef]

6. Motelica, L.; Ficai, D.; Ficai, A.; Oprea, O.C.; Kaya, D.A.; Andronescu, E. Biodegradable Antimicrobial Food Packaging: Trends and Perspectives. Foods 2020, 9, 1438. [CrossRef]

7. Radulescu, M.; Ficai, D.; Oprea, O.; Ficai, A.; Andronescu, E.; Holban, A.M. Antimicrobial Chitosan based Formulations with Impact on Different Biomedical Applications. Curr. Pharm. Biotechnol. 2015, 16, 128-136. [CrossRef] [PubMed]

8. Gherasim, O.; Popescu, R.C.; Grumezescu, V.; Mogosanu, G.D.; Mogoanta, L.; Iordache, F.; Holban, A.M.; Vasile, B.S.; Birca, A.C.; Oprea, O.C.; et al. MAPLE Coatings Embedded with Essential Oil-Conjugated Magnetite for Anti-Biofilm Applications. Materials 2021, 14, 1612. [CrossRef] [PubMed] 
9. Borkowski, D.; Krucinska, I.; Draczynski, Z. Preparation of Nanocomposite Alginate Fibers Modified with Titanium Dioxide and Zinc Oxide. Polymers 2020, 12, 1040. [CrossRef]

10. Fahmy, A.; Khafagy, R.M.; Elhaes, H.; Ibrahim, M.A. Molecular properties of polyvinyl alcohol/sodium alginate composite. Biointerface Res. Appl. Chem. 2020, 10, 4734-4739.

11. Vizzini, P.; Beltrame, E.; Zanet, V.; Vidic, J.; Manzano, M. Development and Evaluation of qPCR Detection Method and Zn$\mathrm{MgO} /$ Alginate Active Packaging for Controlling Listeria monocytogenes Contamination in Cold-Smoked Salmon. Foods 2020, 9, 1353. [CrossRef] [PubMed]

12. Paduraru, A.; Ghitulica, C.; Trusca, R.; Surdu, V.A.; Neacsu, I.A.; Holban, A.M.; Birca, A.C.; Iordache, F.; Vasile, B.S. Antimicrobial Wound Dressings as Potential Materials for Skin Tissue Regeneration. Materials 2019, 12, 1859. [CrossRef] [PubMed]

13. Senturk Parreidt, T.; Muller, K.; Schmid, M. Alginate-Based Edible Films and Coatings for Food Packaging Applications. Foods 2018, 7, 170. [CrossRef]

14. Anugrah, D.S.B.; Alexander, H.; Pramitasari, R.; Hudiyanti, D.; Sagita, C.P. A Review of Polysaccharide-Zinc Oxide Nanocomposites as Safe Coating for Fruits Preservation. Coatings 2020, 10, 988. [CrossRef]

15. Avramescu, S.M.; Butean, C.; Popa, C.V.; Ortan, A.; Moraru, I.; Temocico, G. Edible and Functionalized Films/CoatingsPerformances and Perspectives. Coatings 2020, 10, 687. [CrossRef]

16. Bakil, S.N.A.; Kamal, H.; Abdullah, H.Z.; Idris, M.I. Sodium Alginate-Zinc Oxide Nanocomposite Film for Antibacterial Wound Healing Applications. Biointerface Res. Appl. Chem. 2020, 10, 6289-6296.

17. Naskar, A.; Jana, B.; Kim, H.G.; Kwac, L.K. Effect of Ag2O on cell viability of ZnO nanoparticle synthesized by low temperature solution synthesis process. Biointerface Res. Appl. Chem. 2019, 9, 4011-4014.

18. Motelica, L.; Popescu, A.; Razvan, A.G.; Oprea, O.; Trusca, R.D.; Vasile, B.S.; Dumitru, F.; Holban, A.M. Facile Use of ZnO Nanopowders to Protect Old Manual Paper Documents. Materials 2020, 13, 5452. [CrossRef]

19. Motelica, L.; Marinof, L.; Holban, A.; Vasile, B.S.; Ficai, A. Optical, Photocatalytic and Antibacterial Properties of Zinc Oxide Nanoparticles Obtained by a Solvothermal Method. UPB. Sci. Bull. Ser. B 2020, 82, 59-70.

20. Vaja, F.; Comanescu, C.; Oprea, O.; Ficai, D.; Guran, C. Effects of ZnO Nanoparticles on the Wet Scrub Resistance and Photocatalytic Properties of Acrylic Coatings. Revista Chimie 2012, 63, 722-726.

21. Vaja, F.; Ficai, D.; Ficai, A.; Oprea, O.; Guran, C. Multifunctional advanced coatings based on ZnO/M obtained by nanocasting method. J. Optoelectron. Adv. Mater. 2013, 15, 107-113.

22. Oprea, O.; Andronescu, E.; Ficai, D.; Ficai, A.; Oktar, F.N.; Yetmez, M. ZnO Applications and Challenges. Curr. Org. Chem. 2014, 18, 192-203. [CrossRef]

23. Patino-Herrera, R.; Catarino-Centeno, R.; Robles-Martinez, M.; Zarate, M.G.M.; Flores-Arriaga, J.C.; Perez, E. Antimycotic activity of zinc oxide decorated with silver nanoparticles against Trichophyton mentagrophytes. Powder Technol. 2018, 327, 381-391. [CrossRef]

24. Wasim, M.; Khan, M.R.; Mushtaq, M.; Naeem, A.; Han, M.C.; Wei, Q.F. Surface Modification of Bacterial Cellulose by Copper and Zinc Oxide Sputter Coating for UV-Resistance/Antistatic/Antibacterial Characteristics. Coatings 2020, 10, 364. [CrossRef]

25. Sabry, N.M.; Tolba, S.T.M.; Abdel-Gawad, F.K.; Bassem, S.M.; Nassar, H.; El-Taweel, G.E.; Ibrahim, M.A. On the molecular modeling analyses of the interaction between nano zinc oxide and bacteria. Biointerface Res. Appl. Chem. 2018, 8, $3294-3297$.

26. Husain, Q. An overview on the green synthesis of nanoparticles and other nano-materials using enzymes and their potential applications. Biointerface Res. Appl. Chem. 2019, 9, 4255-4271.

27. Vasile, O.R.; Serdaru, I.; Andronescu, E.; Trusca, R.; Surdu, V.A.; Oprea, O.; Ilie, A.; Vasile, B.S. Influence of the size and the morphology of ZnO nanoparticles on cell viability. Comptes Rendus Chim. 2015, 18, 1335-1343. [CrossRef]

28. Tymoszuk, A.; Wojnarowicz, J. Zinc Oxide and Zinc Oxide Nanoparticles Impact on In Vitro Germination and Seedling Growth inAllium cepaL. Materials 2020, 13, 2784. [CrossRef] [PubMed]

29. Taha, A.; Ben Aissa, M.; Da'na, E. Green Synthesis of an Activated Carbon-Supported Ag and ZnO Nanocomposite for Photocatalytic Degradation and Its Antibacterial Activities. Molecules 2020, 25, 1586. [CrossRef] [PubMed]

30. Kumar, S.; Mudai, A.; Roy, B.; Basumatary, I.B.; Mukherjee, A.; Dutta, J. Biodegradable Hybrid Nanocomposite of Chitosan/Gelatin and Green Synthesized Zinc Oxide Nanoparticles for Food Packaging. Foods 2020, 9, 1143. [CrossRef] [PubMed]

31. Espitia, P.J.P.; Otoni, C.G.; Soares, N.F.F. Zinc Oxide Nanoparticles for Food Packaging Applications. Antimicrob. Food Packag. 2016, 425-431. [CrossRef]

32. Kumar, S.; Boro, J.C.; Ray, D.; Mukherjee, A.; Dutta, J. Bionanocomposite films of agar incorporated with ZnO nanoparticles as an active packaging material for shelf life extension of green grape. Heliyon 2019, 5, e01867. [CrossRef] [PubMed]

33. Al-Naamani, L.; Dutta, J.; Dobretsov, S. Nanocomposite Zinc Oxide-Chitosan Coatings on Polyethylene Films for Extending Storage Life of Okra (Abelmoschus esculentus). Nanomaterials 2018, 8, 479. [CrossRef]

34. Istrati, D.; Lacatusu, I.; Bordei, N.; Badea, G.; Oprea, O.; Stefan, L.M.; Stan, R.; Badea, N.; Meghea, A. Phyto-mediated nanostructured carriers based on dual vegetable actives involved in the prevention of cellular damage. Mater. Sci. Eng. C-Mater. Biol. Appl. 2016, 64, 249-259. [CrossRef]

35. Lacatusu, I.; Badea, N.; Niculae, G.; Bordei, N.; Stan, R.; Meghea, A. Lipid nanocarriers based on natural compounds: An evolving role in plant extract delivery. Eur. J. Lipid Sci. Technol. 2014, 116, 1708-1717. [CrossRef]

36. Caputo, L.; Cornara, L.; Bazzicalupo, M.; de Francesco, C.; de Feo, V.; Trombetta, D.; Smeriglio, A. Chemical Composition and Biological Activities of Essential Oils from Peels of Three Citrus Species. Molecules 2020, 25, 1890. [CrossRef] 
37. Radulescu, M.; Andronescu, E.; Cirja, A.; Holban, A.M.; Mogoanta, L.; Balseanu, T.A.; Catalin, B.; Neagu, T.P.; Lascar, I.; Florea, D.A.; et al. Antimicrobial coatings based on zinc oxide and orange oil for improved bioactive wound dressings and other applications. Rom. J. Morphol. Embryol. 2016, 57, 107-114.

38. Zhang, H.J.; Wang, J.Q. Constituents of the Essential Oils of Garlic and Citronella and Their Vapor-phase Inhibition Mechanism against S. aureus. Food Sci. Technol. Res. 2019, 25, 65-74. [CrossRef]

39. Tadtong, S.; Watthanachaiyingcharoen, R.; Kamkaen, N. Antimicrobial Constituents and Synergism Effect of the Essential Oils from Cymbopogon citratus and Alpinia galanga. Nat. Prod. Commun. 2014, 9, 277-280. [CrossRef]

40. Francikowski, J.; Baran, B.; Cup, M.; Janiec, J.; Krzyzowski, M. Commercially Available Essential Oil Formulas as Repellents Against the Stored-Product Pest Alphitobius diaperinus. Insects 2019, 10, 96. [CrossRef]

41. Go, E.J.; Song, K.B. Effect of java citronella essential oil addition on the physicochemical properties of Gelidium corneum-chitosan composite films. Food Sci. Biotechnol. 2020, 29, 909-915. [CrossRef]

42. Budiati, T.; Suryaningsih, W.; Umaroh, S.; Poerwanto, B.; Bakri, A.; Kurniawati, E. Antimicrobial activity of essential oil from Indonesian medicinal plants against food-borne pathogens. In Proceedings of the 1st International Conference on Food and Agriculture, Bali, Indonesia, 20-21 October 2018; p. 207.

43. De Silva, B.C.J.; Hossain, S.; Wimalasena, S.H.M.P.; Pathirana, H.N.K.S.; Dahanayake, P.S.; Heo, G.J. Comparative in vitro efficacy of eight essential oils as antibacterial agents against pathogenic bacteria isolated from pet-turtles. Vet. Med. 2018, 63, 335-343. [CrossRef]

44. Munteanu, S.B.; Vasile, C. Vegetable Additives in Food Packaging Polymeric Materials. Polymers 2020, 12, 28. [CrossRef]

45. Valdes, A.; Garcia-Serna, E.; Martinez-Abad, A.; Vilaplana, F.; Jimenez, A.; Garrigos, M.C. Gelatin-Based Antimicrobial Films Incorporating Pomegranate (Punica granatum L.) Seed Juice by-Product. Molecules 2020, 25, 166.

46. Becerril, R.; Nerin, C.; Silva, F. Encapsulation Systems for Antimicrobial Food Packaging Components: An Update. Molecules 2020, 25, 1134. [CrossRef]

47. Mallakpour, S.; Sirous, F.; Hussain, C.M. A journey to the world of fascinating ZnO nanocomposites made of chitosan, starch, cellulose, and other biopolymers: Progress in recent achievements in eco-friendly food packaging, biomedical, and water remediation technologies. Int. J. Biol. Macromol. 2021, 170, 701-716. [CrossRef]

48. Yadav, S.; Mehrotra, G.K.; Dutta, P.K. Chitosan based ZnO nanoparticles loaded gallic-acid films for active food packaging. Food Chem. 2021, 334. [CrossRef] [PubMed]

49. Buyana, B.; Aderibigbe, B.A.; Ndinteh, D.T.; Fonkui, Y.T.; Kumar, P. Alginate-pluronic topical gels loaded with thymol, norfloxacin and ZnO nanoparticles as potential wound dressings. J. Drug Deliv. Sci. Technol. 2020, 60, 101960. [CrossRef]

50. Al-Shabib, N.A.; Husain, F.M.; Ahmed, F.; Khan, R.A.; Ahmad, I.; Alsharaeh, E.; Khan, M.S.; Hussain, A.; Rehman, M.T.; Yusuf, M.; et al. Biogenic synthesis of Zinc oxide nanostructures from Nigella sativa seed: Prospective role as food packaging material inhibiting broad-spectrum quorum sensing and biofilm. Sci. Rep. 2016, 6, 36761. [CrossRef]

51. Shi, L.E.; Li, Z.H.; Zheng, W.; Zhao, Y.F.; Jin, Y.F.; Tang, Z.X. Synthesis, antibacterial activity, antibacterial mechanism and food applications of ZnO nanoparticles: A review. Food Addit. Contam. Part A 2014, 31, 173-186. [CrossRef]

52. McClements, D.J.; Xiao, H. Is nano safe in foods? Establishing the factors impacting the gastrointestinal fate and toxicity of organic and inorganic food-grade nanoparticles. Sci. Food 2017, 1, 6.

53. Sruthi, S.; Ashtami, J.; Mohanan, P.V. Biomedical application and hidden toxicity of Zinc oxide nanoparticles. Mater. Today Chem. 2018, 10, 175-186. [CrossRef]

54. Vandebriel, R.J.; de Jong, W.H. A review of mammalian toxicity of ZnO nanoparticles. Nanotechnol. Sci. Appl. 2012, 5, 61-71. [CrossRef] [PubMed]

55. El Shemy, M.A.; Azab, N.I.; Salim, R.F. Zinc Oxide Nanoparticles: The Hidden Danger. Int. J. Biochem. Biophys. Mol. Biol. 2017, 2 , 1-9. [CrossRef]

56. Mohammed, Y.H.; Holmes, A.; Haridass, I.N.; Sanchez, W.Y.; Studier, H.; Grice, J.E.; Benson, H.A.E.; Roberts, M.S. Support for the Safe Use of Zinc Oxide Nanoparticle Sunscreens: Lack of Skin Penetration or Cellular Toxicity after Repeated Application in Volunteers. J. Investig. Dermatol. 2019, 139, 308-315. [CrossRef] [PubMed]

57. Feltis, B.N.; OKeefe, S.J.; Harford, A.J.; Piva, T.J.; Turney, T.W.; Wright, P.F.A. Independent cytotoxic and inflammatory responses to zinc oxide nanoparticles in human monocytes and macrophages. Nanotoxicology 2012, 6, 757-765. [CrossRef] [PubMed]

58. Alaraby, M.; Annangi, B.; Hernandez, A.; Creus, A.; Marcos, R. A comprehensive study of the harmful effects of ZnO nanoparticles using Drosophila melanogaster as an in vivo model. J. Hazard. Mater. 2015, 296, 166-174. [CrossRef] [PubMed]

59. Wright, P.F.A. Realistic Exposure Study Assists Risk Assessments of ZnO Nanoparticle Sunscreens and Allays Safety Concerns. J. Investig. Dermatol. 2019, 139, 277-278. [CrossRef]

60. Wright, P.; Jackson, N. Safety of engineered nanomaterials and occupational health and safety issues for commercial scale production. In Handbook of Clinical Nanomedicine: Law, Business, Regulation, Safety, and Risk; Bawa, R., Audette, G., Reese, B., Eds.; Pan Stanford Publishing: Singapore, 2016; pp. 569-619.

61. Souza, V.G.L.; Rodrigues, C.; Valente, S.; Pimenta, C.; Pires, J.R.A.; Alves, M.M.; Santos, C.F.; Coelhoso, I.M.; Fernando, A.L. Eco-Friendly ZnO/Chitosan Bionanocomposites Films for Packaging of Fresh Poultry Meat. Coatings 2020, 10, 110. [CrossRef]

62. Abou Baker, D.H.; Al-Moghazy, M.; ElSayed, A.A.A. The in vitro cytotoxicity, antioxidant and antibacterial potential of Satureja hortensis L. essential oil cultivated in Egypt. Bioorganic Chem. 2020, 95, 103559. [CrossRef] 
63. Sinha, S.; Jothiramajayam, M.; Ghosh, M.; Mukherjee, A. Evaluation of toxicity of essential oils palmarosa, citronella, lemongrass and vetiver in human lymphocytes. Food Chem. Toxicol. 2014, 68, 71-77. [CrossRef]

64. El-Sayed, H.S.; El-Sayed, S.M.; Mabrouk, A.M.M.; Nawwar, G.A.; Youssef, A.M. Development of Eco-friendly Probiotic Edible Coatings Based on Chitosan, Alginate and Carboxymethyl Cellulose for Improving the Shelf Life of UF Soft Cheese. J. Polym. Environ. 2021, 29, 1941-1953. [CrossRef]

65. Kontominas, M.G. Use of Alginates as Food Packaging Materials. Foods 2020, 9, 1440. [CrossRef] [PubMed]

66. Gheorghita, R.; Amariei, S.; Norocel, L.; Gutt, G. New Edible Packaging Material with Function in Shelf Life Extension: Applications for the Meat and Cheese Industries. Foods 2020, 9, 562. [CrossRef]

67. Olivo, P.M.; Scapim, M.R.D.; Miazaki, J.; Madrona, G.S.; Maia, L.F.; Rodrigues, B.M.; Pozza, M.S.D. Sodium alginate with turmeric coating for ripened cheeses. J. Food Sci. Technol. 2020, 57, 2364-2369. [CrossRef] [PubMed]

68. Mahcene, Z.; Khelil, A.; Hasni, S.; Bozkurt, F.; Goudjil, M.B.; Tornuk, F. Home-made cheese preservation using sodium alginate based on edible film incorporating essential oils. J. Food Sci. Technol. 2021, 58, 2406-2419. [CrossRef] [PubMed]

69. El-sayed, S.M.; El-Sayed, H.S.; Salama, H.H.; Abd-Rabou, N.S. Processed Cheese Sauce Functionalized with Microencapsulated Fig Leaves Extract. Egypt. J. Chem. 2021, 64, 1665-1678.

70. Kumar, S.; Mukherjee, A.; Dutta, J. Chitosan based nanocomposite films and coatings: Emerging antimicrobial food packaging alternatives. Trends Food Sci. Technol. 2020, 97, 196-209. [CrossRef]

71. Divsalar, E.; Tajik, H.; Moradi, M.; Forough, M.; Lotfi, M.; Kuswandi, B. Characterization of cellulosic paper coated with chitosan-zinc oxide nanocomposite containing nisin and its application in packaging of UF cheese. Int. J. Biol. Macromol. 2018, 109, 1311-1318. [CrossRef]

72. Arroyo, B.J.; Bezerra, A.C.; Oliveira, L.L.; Arroyo, S.J.; de Melo, E.A.; Santos, A.M.P. Antimicrobial active edible coating of alginate and chitosan add $\mathrm{ZnO}$ nanoparticles applied in guavas (Psidium guajava L.). Food Chem. 2020, 309. [CrossRef] [PubMed]

73. Oprea, O.; Andronescu, E.; Vasile, B.S.; Voicu, G.; Covaliu, C. Synthesis and Characterization of Zno Nanopowder by Non-Basic Route. Dig. J. Nanomater. Biostructures 2011, 6, 1393-1401.

74. Tymczewska, A.; Furtado, B.U.; Nowaczyk, J.; Hrynkiewicz, K.; Szydłowska-Czerniak, A. Development and Characterization of Active Gelatin Films Loaded with Rapeseed Meal Extracts. Materials 2021, 14, 2869. [CrossRef]

75. Li, W.; Zheng, K.; Chen, H.; Feng, S.; Wang, W.; Qin, C. Influence of Nano Titanium Dioxide and Clove Oil on Chitosan-Starch Film Characteristics. Polymers 2019, 11, 1418. [CrossRef]

76. Socaciu, M.I.; Fogarasi, M.; Semeniuc, C.A.; Socaci, S.A.; Rotar, M.A.; Muresan, V.; Pop, O.L.; Vodnar, D.C. Formulation and Characterization of Antimicrobial Edible Films Based on Whey Protein Isolate and Tarragon Essential Oil. Polymers 2020, 12, 1748. [CrossRef]

77. Mohammed, H.B.; Rayyif, S.M.I.; Curutiu, C.; Birca, A.C.; Oprea, O.C.; Grumezescu, A.M.; Ditu, L.M.; Gheorghe, I.; Chifiriuc, M.C.; Mihaescu, G.; et al. Eugenol-Functionalized Magnetite Nanoparticles Modulate Virulence and Persistence in Pseudomonas aeruginosa Clinical Strains. Molecules 2021, 26, 2189. [CrossRef]

78. Wang, H.; Wan, Y.F.; Wang, W.; Li, W.J.; Zhu, J. Effect of calcium ions on the III steps of self-assembly of SA investigated with atomic force microscopy. Int. J. Food Prop. 2018, 21, 1995-2006. [CrossRef]

79. Kucuk, G.S.; Celik, O.F.; Mazi, B.G.; Ture, H. Evaluation of alginate and zein films as a carrier of natamycin to increase the shelf life of kashar cheese. Packag. Technol. Sci. 2020, 33, 39-48. [CrossRef]

80. Fernandez-Marin, R.; Mujtaba, M.; Cansaran-Duman, D.; Ben Salha, G.; Sanchez, M.A.A.; Labidi, J.; Fernandes, S.C.M. Effect of Deterpenated Origanum majorana L. Essential Oil on the Physicochemical and Biological Properties of Chitosan/beta-Chitin Nanofibers Nanocomposite Films. Polymers 2021, 13, 1507. [PubMed]

81. Ngo, T.M.P.; Dang, T.M.Q.; Tran, T.X.; Rachtanapun, P. Effects of Zinc Oxide Nanoparticles on the Properties of Pectin/Alginate Edible Films. Int. J. Polym. Sci. 2018, 2018, 1-9. [CrossRef]

82. Liu, J.; Liu, C.; Zheng, X.J.; Chen, M.; Tang, K.Y. Soluble soybean polysaccharide/nano zinc oxide antimicrobial nanocomposite films reinforced with microfibrillated cellulose. Int. J. Biol. Macromol. 2020, 159, 793-803. [CrossRef]

83. Dou, Y.; Huang, X.; Zhang, B.N.; He, M.; Yin, G.Q.; Cui, Y.D. Preparation and characterization of a dialdehyde starch crosslinked feather keratin film for food packaging application. Rsc Adv. 2015, 5, 27168-27174. [CrossRef]

84. Trandafilovic, L.V.; Bozanic, D.K.; Dimitrijevic-Brankovic, S.; Luyt, A.S.; Djokovic, V. Fabrication and antibacterial properties of ZnO-alginate nanocomposites. Carbohydr. Polym. 2012, 88, 263-269. [CrossRef]

85. Oprea, O.; Vasile, O.R.; Voicu, G.; Andronescu, E. The Influence of the Thermal Treatment on Luminescence Properties of Zno. Dig. J. Nanomater. Biostructures 2013, 8, 747-756.

86. Lei, J.; Kim, J.H.; Jeon, Y.S. Preparation and properties of alginate/polyaspartate composite hydrogels. Macromol. Res. 2008, 16, 45-50. [CrossRef]

87. Xing, Y.G.; Li, X.L.; Guo, X.L.; Li, W.X.; Chen, J.W.; Liu, Q.; Xu, Q.L.; Wang, Q.; Yang, H.; Shui, Y.R.; et al. Effects of Different $\mathrm{TiO}(2)$ Nanoparticles Concentrations on the Physical and Antibacterial Activities of Chitosan-Based Coating Film. Nanomaterials 2020, 10, 1365. [CrossRef] [PubMed]

88. Hasan, I.; Shekhar, C.; Bin Sharfan, I.I.; Khan, R.A.; Alsalme, A. Ecofriendly Green Synthesis of the ZnO-Doped CuO@Alg Bionanocomposite for Efficient Oxidative Degradation of p-Nitrophenol. Acs Omega 2020, 5, 32011-32022. [CrossRef]

89. Fajardo, A.R.; Silva, M.B.; Lopes, L.C.; Piai, J.F.; Rubira, A.F.; Muniz, E.C. Hydrogel based on an alginate-Ca2+/chondroitin sulfate matrix as a potential colon-specific drug delivery system. Rsc Adv. 2012, 2, 11095-11103. [CrossRef] 
90. Qiu, B.; Xu, X.F.; Deng, R.H.; Xia, G.Q.; Shang, X.F.; Zhou, P.H. Construction of chitosan/ZnO nanocomposite film by in situ precipitation. Int. J. Biol. Macromol. 2019, 122, 82-87. [CrossRef]

91. Zayed, M.; Othman, H.; Ghazal, H.; Hassabo, A.G. Psidium Guajava Leave Extract as Reducing Agent for Synthesis of Zinc Oxide Nanoparticles and its Application to Impart Multifunctional Properties for Cellulosic Fabrics. Biointerface Res. Appl. Chem. 2021, 11, 13535-13556.

92. Naidu, D.S.; John, M.J. Effect of Clay Nanofillers on the Mechanical and Water Vapor Permeability Properties of Xylan-Alginate Films. Polymers 2020, 12, 2279. [CrossRef]

93. Timung, R.; Barik, C.R.; Purohit, S.; Goud, V.V. Composition and anti-bacterial activity analysis of citronella oil obtained by hydrodistillation: Process optimization study. Ind. Crop. Prod. 2016, 94, 178-188. [CrossRef]

94. Lan, W.T.; Li, S.Y.; Shama, S.; Zhao, Y.Q.; Sameen, D.E.; He, L.; Liu, Y.W. Investigation of Ultrasonic Treatment on Physicochemical, Structural and Morphological Properties of Sodium Alginate/AgNPs/Apple Polyphenol Films and Its Preservation Effect on Strawberry. Polymers 2020, 12, 2096. [CrossRef] [PubMed]

95. Jost, V.; Kobsik, K.; Schmid, M.; Noller, K. Influence of plasticiser on the barrier, mechanical and grease resistance properties of alginate cast films. Carbohydr. Polym. 2014, 110, 309-319. [CrossRef]

96. Naik, M.I.; Fomda, B.A.; Jaykumar, E.; Bhat, J.A. Antibacterial activity of lemongrass (Cymbopogon citratus) oil against some selected pathogenic bacterias. Asian Pac. J. Trop. Med. 2010, 3, 535-538. [CrossRef]

97. Viktorova, J.; Stupak, M.; Rehorova, K.; Dobiasova, S.; Hoang, L.; Hajslova, J.; Thanh, T.V.; Tri, L.V.; Tuan, N.V.; Ruml, T. Lemon Grass Essential Oil does not Modulate Cancer Cells Multidrug Resistance by Citral-Its Dominant and Strongly Antimicrobial Compound. Foods 2020, 9, 585. [CrossRef]

98. Breijyeh, Z.; Jubeh, B.; Karaman, R. Resistance of Gram-Negative Bacteria to Current Antibacterial Agents and Approaches to Resolve It. Molecules 2020, 25, 1340. [CrossRef] [PubMed]

99. Nottagh, S.; Hesari, J.; Peighambardoust, S.H.; Rezaei-Mokarram, R.; Jafarizadeh-Malmiri, H. Effectiveness of edible coating based on chitosan and Natamycin on biological, physico-chemical and organoleptic attributes of Iranian ultra-filtrated cheese. Biologia 2020, 75, 605-611. [CrossRef] 